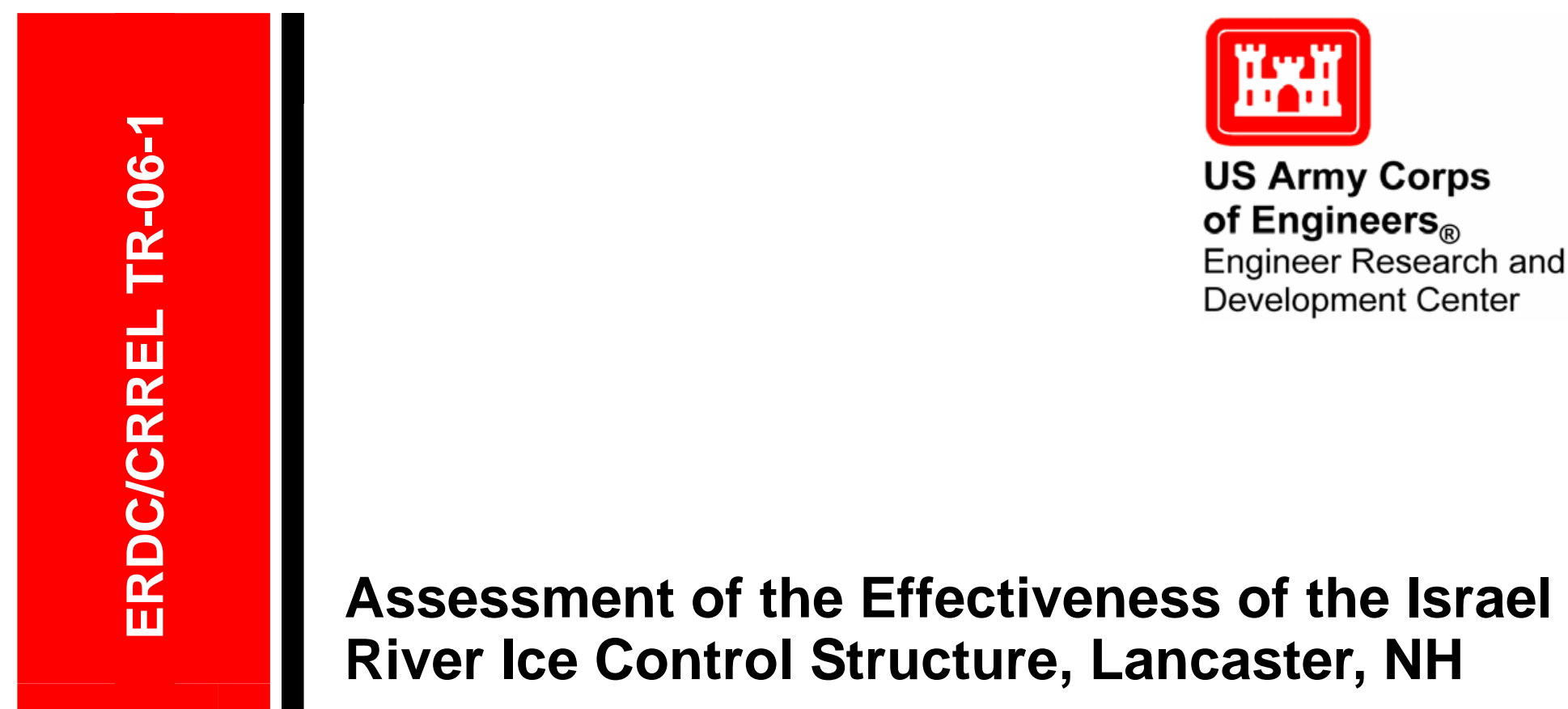

Carrie M. Vuyovich and Kathleen D. White

January 2006

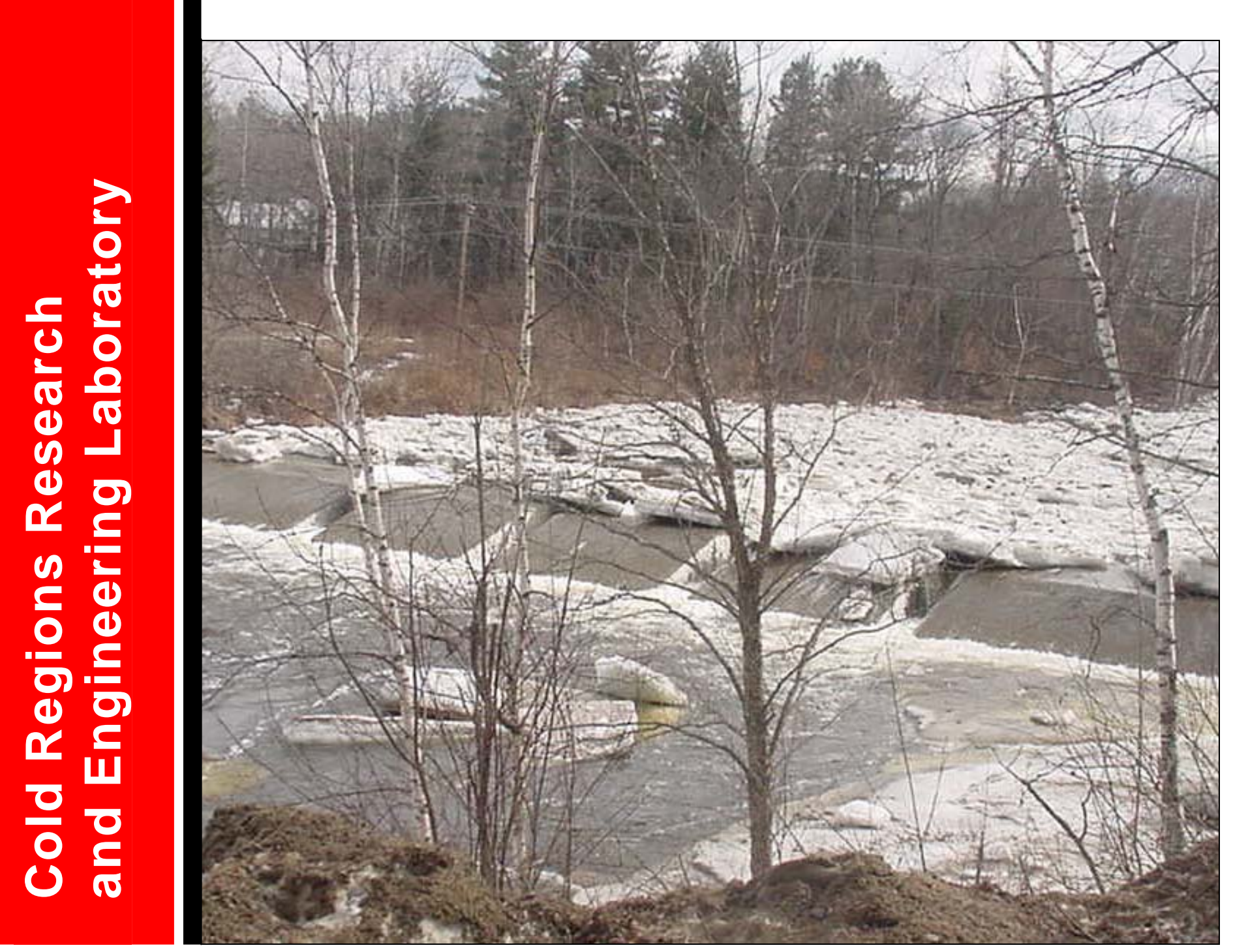


Cover: Ice cover retained upstream of the ICS during the 24 March 2003 ice event. 


\section{Assessment of the Effectiveness of the Israel River Ice Control Structure, Lancaster, NH}

Carrie M. Vuyovich and Kathleen D. White

Cold Regions Research and Engineering Laboratory

U.S. Army Engineer Research and Development Center

72 Lyme Road

Hanover, New Hampshire 03755-1290

Approved for public release; distribution is unlimited.

\footnotetext{
Prepared for U.S. Army Corps of Engineers, New England District

With support from USACE Wetlands Regulatory Assistance Program
} 


\section{ABSTRACT}

The Israel River in Lancaster, NH, has experienced numerous significant ice jams. In 1981 the New England Division of the U.S. Army Corps of Engineers completed an ice control structure (ICS) located about 0.5 miles upstream from the center of town. The 9-ft-high concrete-capped gabion weir was designed to retain both frazil ice during freezeup and broken ice after ice cover breakup. In recent years, the ICS has fallen into disrepair. The structure's current condition, combined with operation and maintenance safety issues and concerns about fish passage, have prompted the town to pursue the option of its removal. New England District Corps of Engineers, through the Corps' Wetlands Regulatory Assistance Program (WRAP), requested CRREL's assistance in determining whether the ICS has been effective in reducing the impacts of ice jams since its construction 24 years ago. Study results show that while the frequency of ice jam events in Lancaster has not decreased, the severity of ice jam flooding has, even though winter conditions at the time of the events have not lessened. The results of this preliminary analysis indicate that the Israel River ICS does provide some flood damage reduction benefit to the Town of Lancaster.

DISCLAIMER: The contents of this report are not to be used for advertising, publication, or promotional purposes. Citation of trade names does not constitute an official endorsement or approval of the use of such commercial products. All product names and trademarks cited are the property of their respective owners. The findings of this report are not to be construed as an official Department of the Army position unless so designated by other authorized documents. 


\section{CONTENTS}

CONVERSION FACTORS, NON-SI TO SI UNITS OF MEASUREMENT ..... v

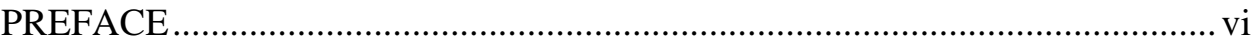

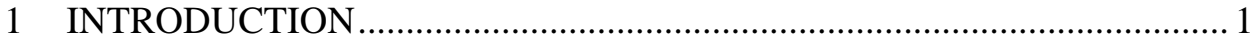

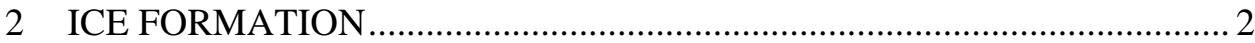

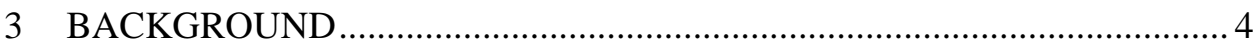

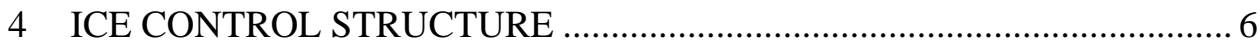

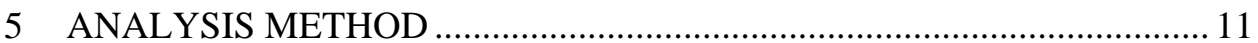

6 HYDROLOGICAL AND METEOROLOGICAL DATA COLLECTION.. 12

Estimation of Ice Thickness ....................................................................... 13

Historical Ice Events on the Israel River at Lancaster.................................... 14

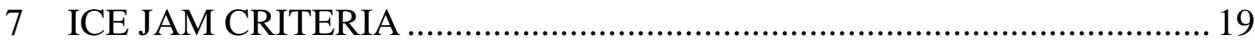

8 IMPLICATIONS OF REBUILT MAIN STREET BRIDGE ......................... 23

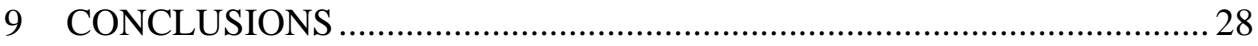

10 RECOMMENDATIONS FOR FURTHER STUDY ................................. 29

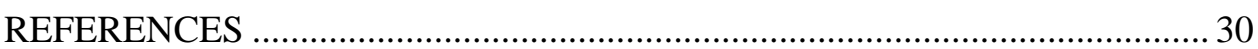

\section{ILLUSTRATIONS}

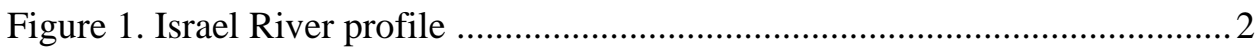

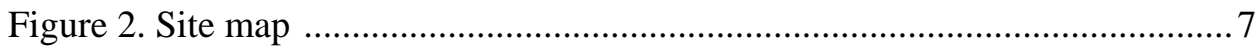

Figure 3. Ice retention upstream from the ICS during ice jams .......................... 8

Figure 4. Example of ice-affected stage-discharge curve ................................. 9

Figure 5. Ice-affected stage-discharge curve for the Allagash River near

Allagash, Maine, 2004 ................................................................... 9

Figure 6. Aerial photos of the 24 March 2003 ice event ..................................... 10

Figure 7. Average winter-season temperatures in Lancaster, $\mathrm{NH}$........................ 13

Figure 8. Estimated ice thickness for each recorded ice event in Lancaster, $\mathrm{NH}$.......................................................................... 14

Figure 9. Recorded or estimated stages for Lancaster, NH, ice events ............... 18

Figure 10. Ice retention upstream from the ICS during construction,

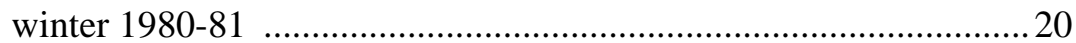

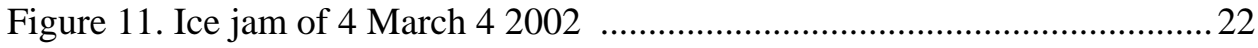


Figure 12. Double-arch Main St. Bridge circa 1928, replaced in 1989-90 ......... 23

Figure 13. The Main Street Bridge during the March 1968 ice jam ................... 24

Figure 14. Ice building up on the upstream face of the single-span Main Street Bridge in April 2001 ................................................... 25

Figure 15. Upstream view of the Main Street Bridge after the ice jam of January 1999 26

\section{TABLES}

Table 1. Recorded ice events in Lancaster, NH, before the completion of the ICS

Table 2. Recorded ice events in Lancaster, $\mathrm{NH}$, after the completion

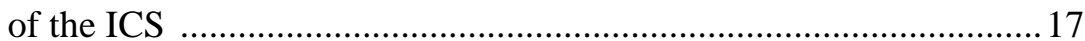

Table 3. Significant ice jam events predicted in Lancaster, NH ........................ 20 


\section{CONVERSION FACTORS, NON-SI TO SI UNITS OF MEASUREMENT}

Non-SI units of measurement used in this report can be converted to SI units as follows:

\begin{tabular}{|l|c|l|}
\hline Multiply & By & To obtain \\
\hline degrees Fahrenheit & $5 / 9$ & degrees Celsius or kelvins ${ }^{1}$ \\
feet & 0.3048 & meters \\
miles (U.S. statute) & 1.609347 & kilometers \\
square miles & $2,589,998$ & square meters \\
\hline
\end{tabular}

${ }^{1}$ To obtain Celsius $\left({ }^{\circ} \mathrm{C}\right)$ temperature readings from Fahrenheit $\left({ }^{\circ} \mathrm{F}\right)$ readings, use the following formula: ${ }^{\circ} \mathrm{C}=(5 / 9)\left({ }^{\circ} \mathrm{F}-32\right)$. 


\section{PREFACE}

This report was prepared by Carrie M. Vuyovich, Research Hydraulic Engineer, Remote Sensing, GIS, and Water Resources Branch, and Dr. Kathleen D. White, Research Hydraulic Engineer, Environmental Sciences Branch, U.S. Army Cold Regions Research and Engineering Laboratory (CRREL), Engineer Research and Development Center (ERDC), Hanover, New Hampshire. This work was prepared for the New England District, Army Corps of Engineers and funded under the U.S. Army Corps of Engineers Civil Wetlands Regulatory Assistance Program, managed by Robert L. Lazor, with additional support from the Flood and Coastal Storm Damage Reduction Research Program Work Unit Ice-Affected Structures. Technical reviews were provided by Andrew M. Tuthill, Research Hydraulic Engineer, Remote Sensing, GIS, and Water Resources Branch, and by Leonard J. Zabilansky, Civil Engineer, Engineering Resources Branch, CRREL.

This report was prepared under the general supervision of Timothy Pangburn, Chief, Remote Sensing, GIS, and Water Resources Branch; Dr. Lance Hansen, Deputy Director; and James L. Wuebben, Acting Director, CRREL.

The Commander and Executive Director of the Engineer Research and Development Center is COL James R. Rowan. The Director is Dr. James R. Houston. 


\title{
Assessment of the Effectiveness of the Israel River Ice Control Structure, Lancaster, NH
}

\author{
CARRIE M. VUYOVICH AND KATHLEEN D. WHITE
}

\section{INTRODUCTION}

The town of Lancaster, $\mathrm{NH}$, has a long history of ice jams and ice jam flooding. In 1981 the Corps of Engineers built an ice control structure (ICS) in an attempt to alleviate the problem. Since that time no severe ice jam flooding has occurred. However, no studies have been done to determine to what extent, if any, the ICS is responsible for that success. Structural deterioration of the ICS and a desire to restore fish passage upstream from the ICS have resulted in a recommendation by the town to have the dam removed. The purpose of this study is to determine, within the budget constraints and based on existing data, whether the ICS has had any impact in reducing ice-affected floods in Lancaster. This study will not attempt to determine to what extent the ICS has reduced water surface elevations due to ice. For that, a more detailed hydraulic analysis is necessary. 


\section{ICE FORMATION}

Ice formation in the Israel River is heavily influenced by the river's geomorphology and its location near the White Mountains of New Hampshire. The Israel River is approximately 21 miles long and has a drainage area of about 136 square miles at the confluence with the Connecticut River (White and Moore 2002). Elevations in the watershed range from about 5,715 ft at Mt. Jefferson to about $835 \mathrm{ft}$ downstream of Lancaster. The river is generally shallow and relatively steep with a rough bed, until it reaches the mildly sloping reach that forms because of backwater from the confluence with the Connecticut River. The average channel slope for the basin is 0.03 , though the average slope in the reach through Lancaster is about 0.0083 (Provan and Lorber, Inc. 2003). Where the Israel River flows into the Connecticut River, the average slope is about 0.0001 . The backwater from the Connecticut extends approximately 7,900 ft up the Israel River to the location of the abandoned railroad abutments approximately 2,800 ft downstream from the Main Street Bridge in Lancaster. Figure 1 shows the profile of the Israel River.

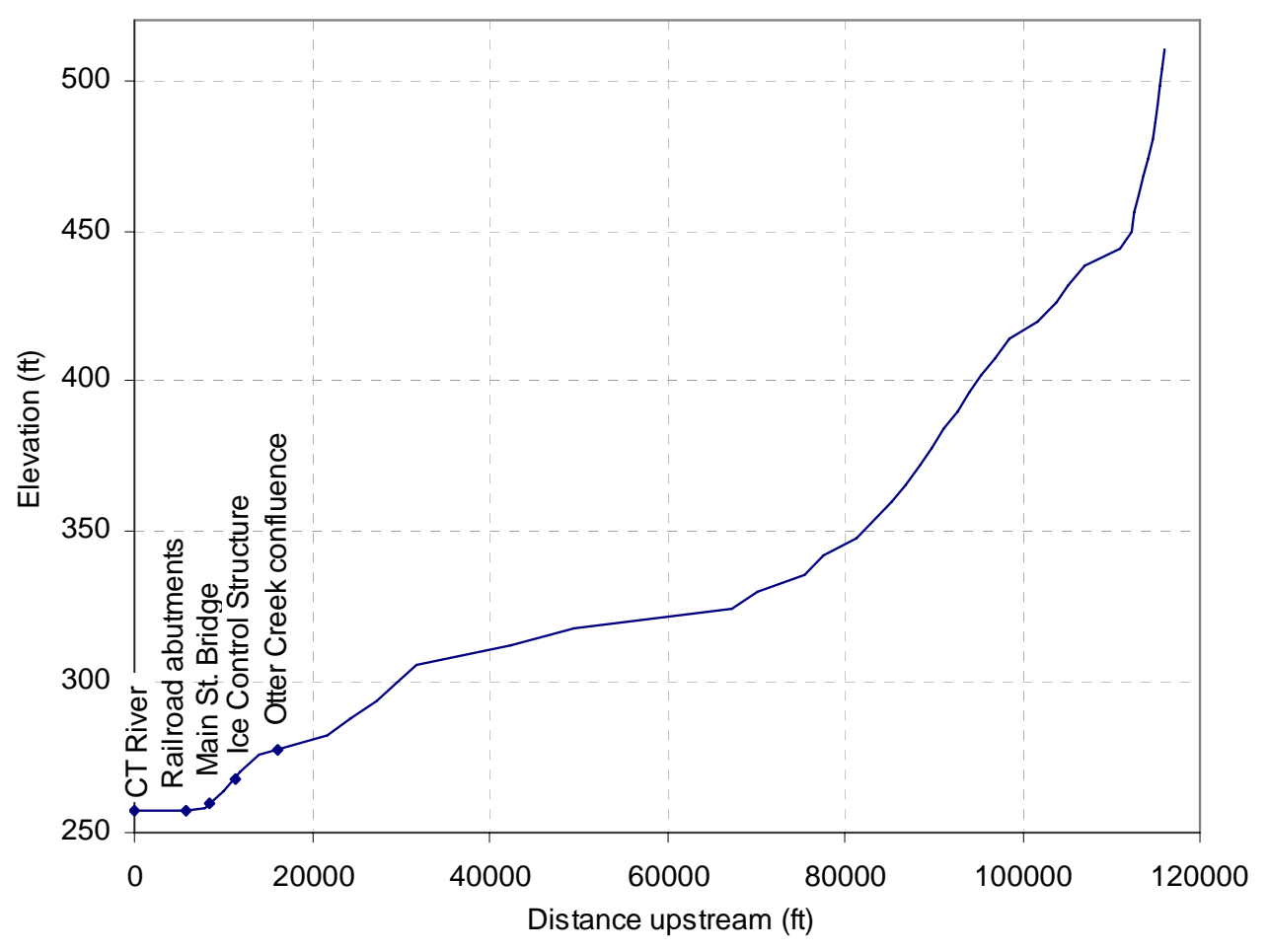

Figure 1. Israel River profile. 
Periodic ice observations by the U.S. Army's Cold Regions Research and Engineering Laboratory (CRREL) over the past 40 years reveal that ice forms in the steeper portions of the river initially along the channel edges and around boulders protruding from the water. The river produces significant frazil ice because of its steep gradient and turbulence. Eventually, open water leads are filled with frazil, forming a solid ice cover that insulates the water, preventing supercooling and further frazil production.

As is typical in many rivers, ice covers are initiated by thermal processes in the slower-moving portions of the river and gradually thicken during the winter. The pool upstream from the ICS and the backwater reach downstream from the abandoned railroad bridge abutments exhibit this type of ice formation. Frazil ice moves downstream and accumulates against or is deposited beneath solid ice covers on slower reaches. Substantial amounts of frazil ice are deposited on the Israel River at the upstream limit of the Connecticut River backwater near the abandoned railroad abutments below the village of Lancaster. These frazil deposits increase the total thickness and strength of the ice cover; frazil ice deposits as much as $7 \mathrm{ft}$ thick have been measured at this location. Frazil ice is also deposited in the pool upstream from the ICS, as intended in the original design.

Ice cover breakup results from thermal or mechanical processes. Thermal breakup, caused when the cover melts and thins as a result of warming air and water temperatures, is largely benign, although it can result in the movement of ice pieces that later jam.

Mechanical breakup occurs when the mechanical forces on the ice cover exceed the resisting forces of the ice. This usually results from increases in flow caused by rapid snowmelt often accompanied by rain. The rising stage lifts the ice. Once the ice cover has lifted, it fractures along the riverbanks and then rapidly breaks into smaller pieces, which begin to move downstream. If the concentration of the moving ice rubble exceeds the transport capacity of the river, an ice jam forms. Ice jams also occur when the breakup ice run impacts an intact ice cover or other obstacles such as bridges or dams. Jams can form as a result of hydraulic or morphological factors (e.g., decrease in energy slope, increase in channel depth or width). In the case of the Israel River, the thicker ice in the backwater reaches of the ICS pool and the Connecticut River initiate ice jamming. As ice accumulates, the jam extends upstream, reducing the channel flow area and causing sudden rises in water level. The severity of flooding is a function of the volume of ice contributing to the ice jam, the ice strength, the discharge rate, and the riverbed geometry. More detailed descriptions of ice formation and breakup processes can be found in the Ice Engineering Manual (USACE 2002a). 


\section{BACKGROUND}

Colonization in the eastern United States initially occurred along rivers because they provided water for water supply, agricultural, industrial, and transportation purposes. Settlers also built dams to utilize the mechanical power provided by rivers, and settlements grew up around these early industries. Lancaster is a typical case, with one early map by J.W. Weeks (1826) showing two and possibly three dams in the river (W.A. Fergusson and Co. 1888). In the latter $19^{\text {th }}$ and early part of the $20^{\text {th }}$ century, four dams were known to exist within Lancaster. NH dam records show that in 1936, an 8-ft-high timber crib dam (NH Dam \#131.01) and a 20-ft-high timber crib dam (\#131.02) were located just downstream and upstream, respectively, of the Main Street Bridge. A third 20-ft-high, 220-ft-long dam (\#131.03) was located near the current site of the ICS, and a 25ft-high timber crib dam (\#131.04) was farther upstream. The role played by the dams in the ice regime was clearly described for the ice event of 1886 (W.A. Fergusson and Co. 1888): "Israel's river, swollen to an enormous degree, broke up the ice, and a tremendous gorge was formed at the head of Frank Smith \& Co.'s mill pond, obstructed by the solid mass of ice formed in the channel during a previous thaw, and which resisted the great force of the flood.” In northern rivers, dam decay and removal affected the hydraulic and sediment regimes. In many cases, these physical changes impacted the ice regime, specifically ice formation, ice cover growth and progression, ice cover breakup, and ice jamming (White and Moore 2002). In the case of Lancaster, the failure of the dams has resulted in increased frequency and severity of jams.

All of these dams were destroyed during large flooding events between 1936 and 1950. Of the seven large floods reported in Lancaster between 1870 and 1940, only two were reported to be caused by ice jams (1886 and 1895), but 15 of the 18 floods between 1940 and 1970 were a result of ice (USACE 1973). Like the 1886 event, some of the worst ice jam flooding in Lancaster has occurred after an early jam has frozen in place, exacerbating jamming problems during subsequent breakup events. For example, the jam of March 1968 followed breakup jams in December and January that froze in place, and four ice jam events were reported in 1953 (USACE 1964), which was the peak ice event after 1886 and before 1968. According to USACE (1964), "Local interests attribute the increasing frequency of ice jams to the loss of two upstream dams, destroyed by past floods. The dams were located about 2,500 and 4,000 feet, respectively, from the Main Street bridge.”

In recent years, freezeup jams have also contributed to the town's ice problems. Freezeup jams are the result of large amounts of frazil ice accumulating 
downstream and blocking the passage of flow. The first recorded freezeup jam in Lancaster occurred in February 1996 (CRREL 2005). An earlier breakup jam left most of the river free of ice and was followed by intense cold weather in which large amounts of frazil were generated. This frazil ice accumulated near the railroad bridge abutments and caused flooding along Canal Street and Water Street. Similar jams have occurred frequently in recent years, though an explanation is unclear. Because the physical processes involved in freezeup ice jams are so different from those that cause breakup ice jams, this study does not address freezeup ice jams. 


\section{ICE CONTROL STRUCTURE}

Following several significant ice jam floods in the 1950s and early 1960s in Lancaster, the Corps of Engineers' New England Division (now District, NAE) recommended the construction of a low, timber crib dam about 4,000 ft upstream from the Main Street Bridge to serve as an ice retention pool (USACE 1964). NAE and the U.S. Army Cold Regions Research and Engineering Laboratory (now ERDC-CRREL) performed a detailed study that resulted in the design of an ice control structure (ICS).

The original design placed the ICS at the confluence of the Israel River and Otter Creek, just upstream from the fourth dam across the river. Following the devastating ice jam flood in 1968, which resulted in the highest recorded flood stage for either open-water or ice-affected flooding, a rock dike with a submarine net was installed on the Israel River just upstream from this confluence to provide additional ice control. However, in 1974 a damaging ice jam flood occurred in Lancaster that was made up of ice from the reach downstream of the dike, and the decision was made to move the site of the ICS to its current location (USACE 1974). Economic and environmental constraints limited the size and scope of the project, which was constructed as a 160-ft-long, 9-ft-high concretecapped gabion weir with four sluiceways intended to enhance fish passage (USACE 1978). The ICS was completed in 1981. Figure 2 shows its location.

The Israel River ICS was originally designed to serve as an ice retention structure during breakup, as well as to reduce the amount of frazil in the Israel River that can contribute to the thick ice cover in the backwater of the Connecticut River. According to the Operations and Maintenance Manual (USACE 1982), stop logs were to be placed in the four sluiceways during the last week in November each year and removed during the last week in April. With the stop logs in place, a small pool forms at about the crest of the weir. In the first few years of operation, several schemes were tried to allow for creation of the pool during the winter months and allow for safe operations at the same time. The stop logs that were initially designed for the structure were found to be too dangerous to remove in the spring. In 1989, bar racks were constructed to replace the stop logs and make the removal easier. Placement of the stop logs or bar racks was done consistently from the time the structure went up until 2003, with the exception of 1984. Because of safety concerns, the bar racks were no longer used after the winter of 2003.

\footnotetext{
* Personal communication, Joyce McGee, Lancaster Town Manager, 2005.
} 


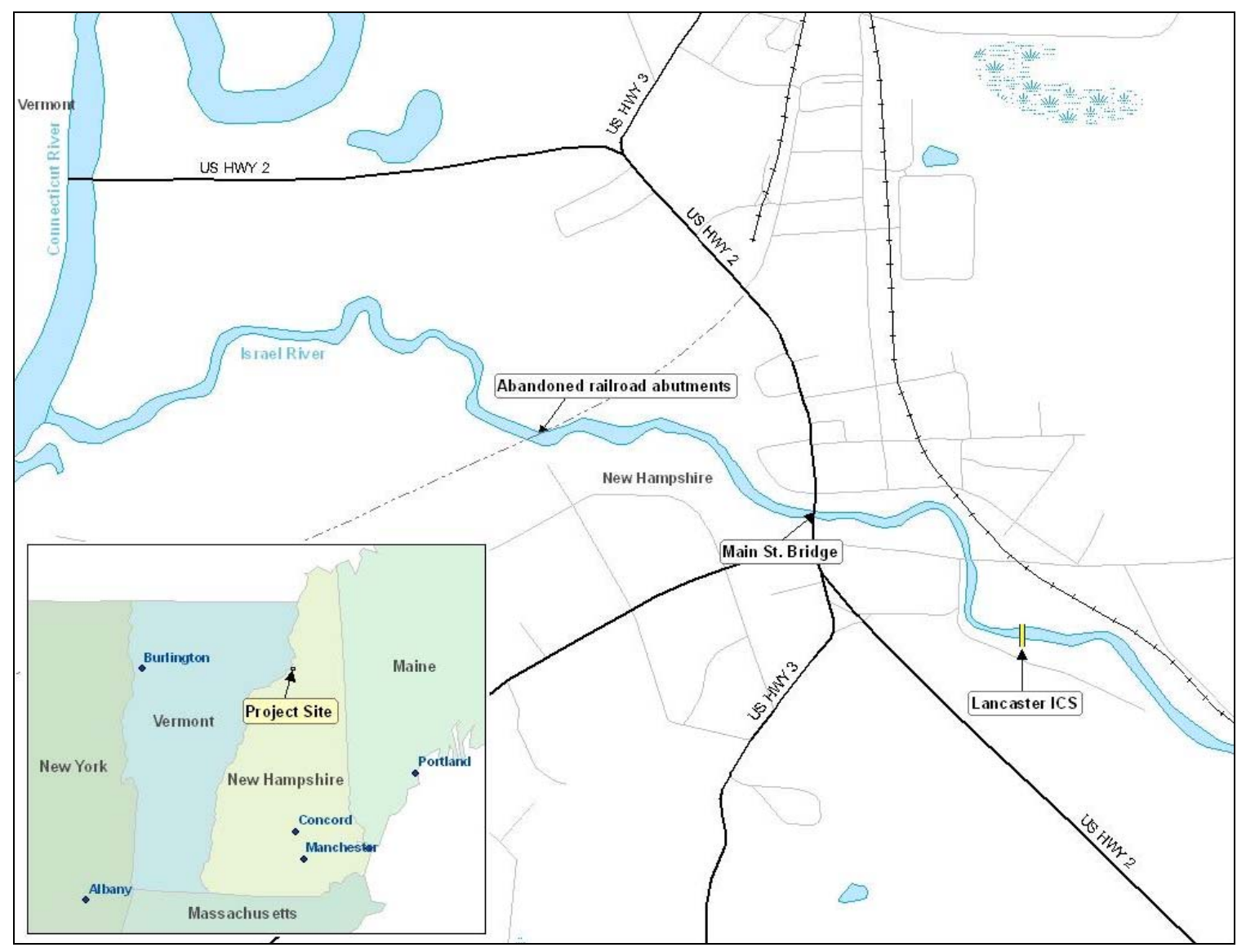

Figure 2. Site map.

A solid ice cover forms on the quiescent water in the ICS pool. Some of the frazil ice produced in the turbulent, supercooled water upstream from the ICS is deposited beneath the ice cover in the pool, slightly reducing the amount transported farther downstream to the Connecticut River confluence. A 1990 progress report indicated that the ice upstream from the ICS was thicker and contained more frazil than the ice cover downstream (Axelson 1990).

Because the ICS pool contains relatively strong thermally grown ice and frazil ice deposits, the ice is thicker than elsewhere in the upstream reaches. More energy is required to lift and break this thicker ice cover. Thus, it tends to break up more slowly than the upstream ice. In addition, the ice cover in the pool must be raised enough to lift over the ICS, so that it not only breaks up later, but more discharge is required to move this ice cover than the upstream ice. The ICS ice cover thus forms an obstruction to the movement of ice downstream toward town, effectively acting as an ice retention structure until the discharge becomes 


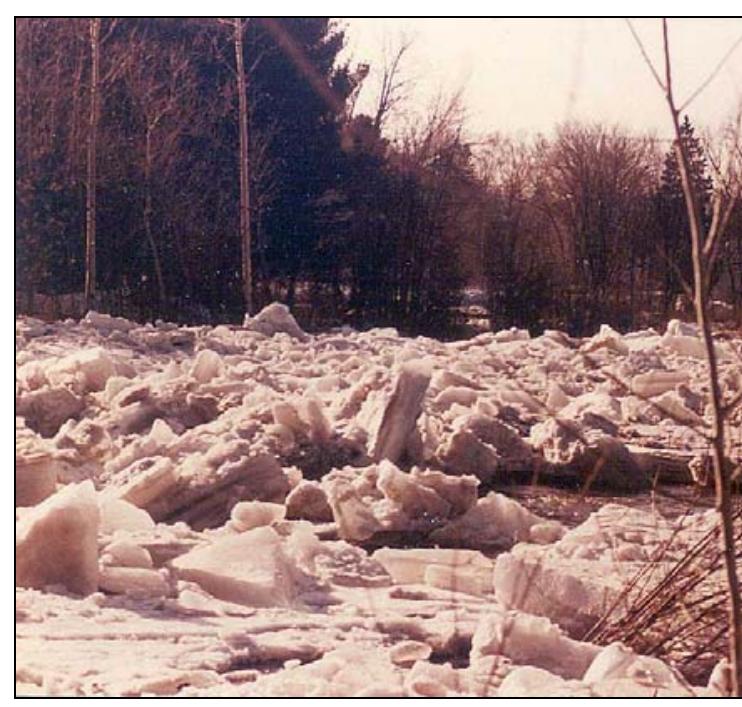

a. Ice jam in the ICS pool, February 1985.

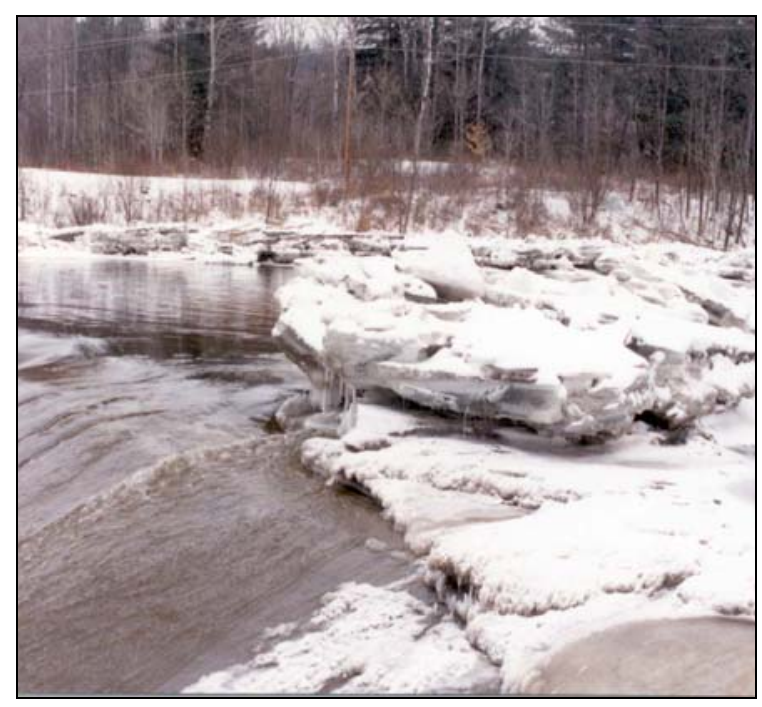

b. Ice above the weir, March 12, 1992.

Figure 3. Ice retention upstream from the ICS during ice jams.

large enough to break up the ice and lift it over the ICS. Figure 3 shows the February 1985 and March 1992 jamming upstream from the ICS.

Figure 4 illustrates the process from competent ice cover to breakup to jamming, followed by jam failure. Following ice cover formation in winter, the stage follows the sheet ice curve as discharge rises until the ice breaks up. If the ice breaks up and moves downstream (i.e., no jam occurs), the stage-discharge curve reverts to the open water curve (i.e., it drops suddenly as in Figure 4). If the ice breaks up but jams, the stage-discharge curve moves suddenly upward from the sheet ice curve to the higher jam curve. The ice jam curve will level off when flow goes over the banks, relieving forces on the jam (the flat portion of the ice jam curve in Figure 4), or the discharge can suddenly drop when the ice jam fails, as shown in Figure 4 where the stage-discharge curve again reverts to the open water curve. A similar curve for a 2004 ice event on the Allagash River near Allagash, Maine, is shown in Figure 5.

The key to ice control in the Israel River is to retain the ice cover on the ICS pool or to otherwise delay the movement of ice from upstream until the discharge has reached the point where the jam downstream in Lancaster fails due to ice forces, deterioration of ice strength caused by increased flow, or some combination of the two. In several events the ice cover is known to have remained above the ICS until the jam in town failed, including during 2003, when the pictures on the cover of this report and in Figure 6 were taken. Anecdotal reports of the 


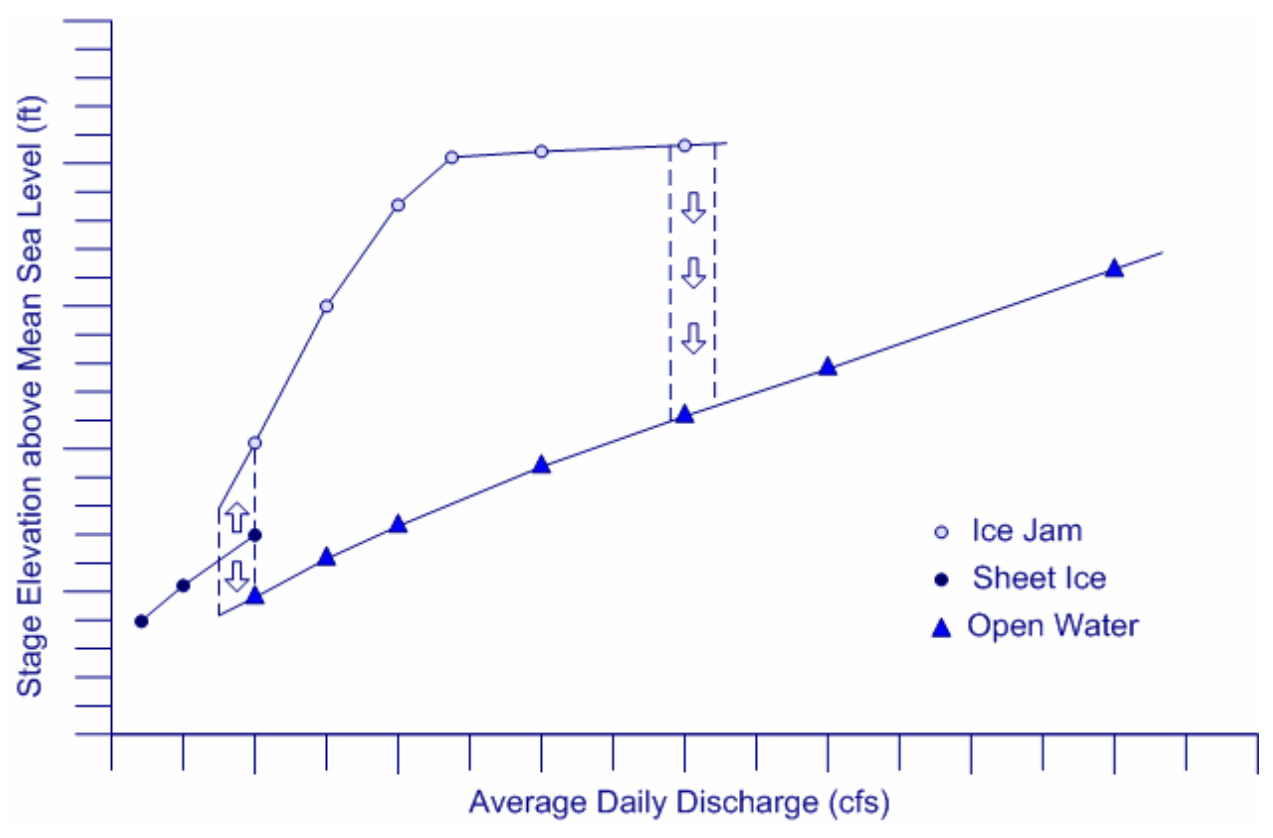

Figure 4. Example of ice-affected stage-discharge curve. (From Tuthill et al. 1996.)

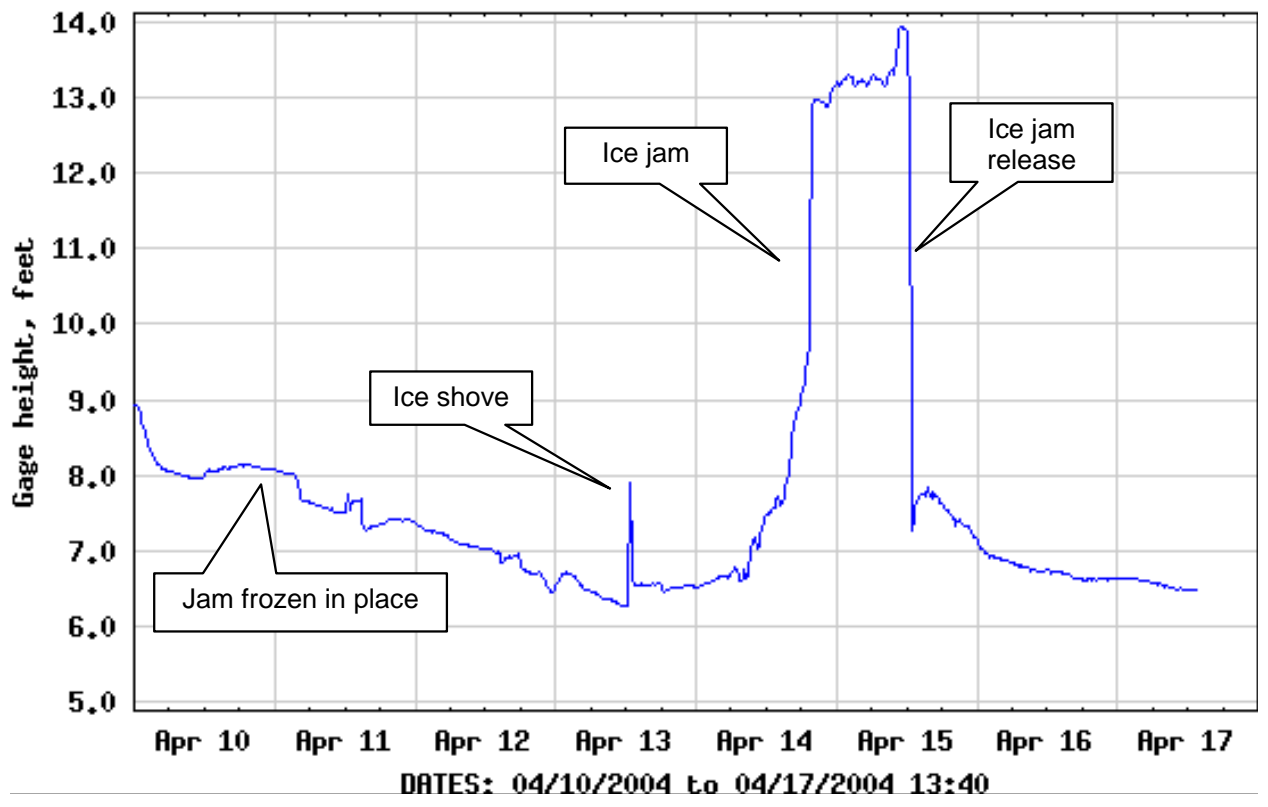

Figure 5. Ice-affected stage-discharge curve for the Allagash River near Allagash, Maine, 2004. (After USGS 2004.) 
sequence of ice movement over the ICS and jam failure in town indicate that the discharge required to pass ice over the ICS may be close to the discharge associated with failure of the jam in town. A detailed hydraulic analysis of the reach, including a rating curve for the ICS, is necessary to confirm this. The cover photograph captures incipient conditions for ice passage over the ICS.

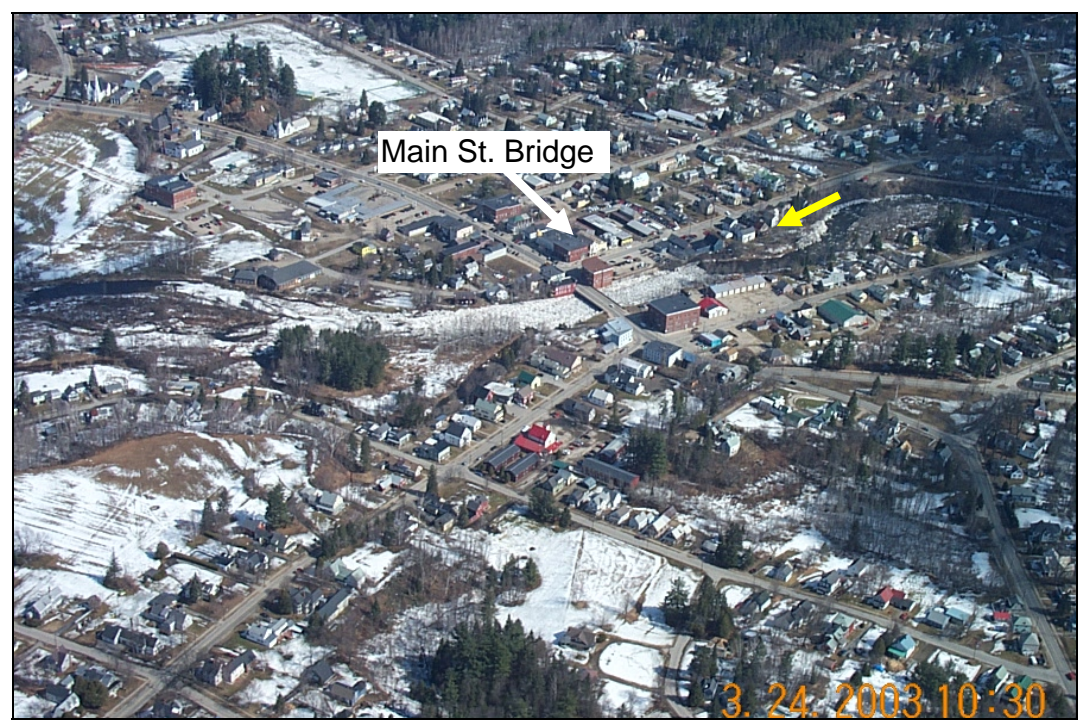

a. Ice jam in town.

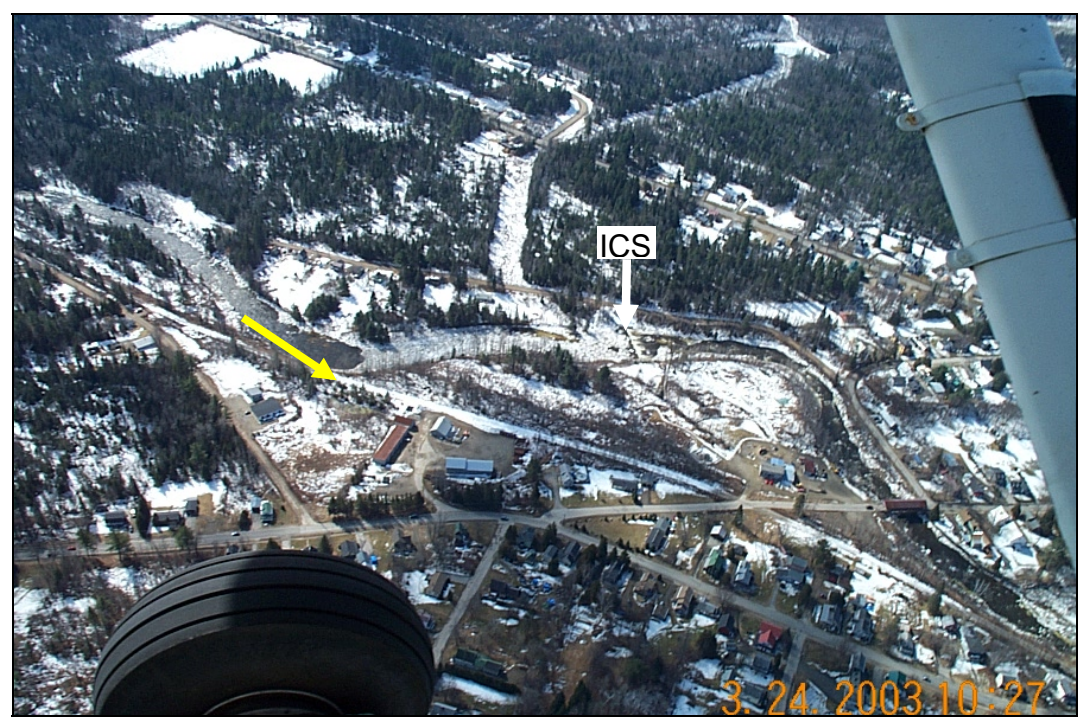

b. Ice held above the ice control structure.

Figure 6. Aerial photos of the 24 March 2003 ice event. The yellow arrows indicate the flow direction. 


\section{ANALYSIS METHOD}

The purpose of this study is to determine, within the budget constraints, whether the ICS has reduced ice-affected floods in Lancaster.

Since the construction of the ICS in 1981, the frequency of ice jams in Lancaster has not changed significantly compared to the pre-ICS period, which is defined as approximately 1950-1980. ${ }^{*}$ The important difference is that, although ice pre- and post-ICS jam frequencies are similar, no significant ice jam floods have occurred in Lancaster in the 24 years since the ICS was built. This analysis therefore concentrates on whether the Lancaster ICS has had an impact on lessening the severity of ice jam flooding. Standard investigations of ice jam occurrence and frequency (e.g., Tuthill et al. 2003, Vuyovich et al. 2005) include the following steps:

- Compile meteorologic and hydrologic data for nearby locations in a database;

- Perform an extensive review of recorded ice events;

- Evaluate the meteorologic and hydrologic database to characterize the conditions at the time and location of an event; and

- Develop a set of threshold values or criteria that are likely to lead to the occurrence of a significant ice jam.

In this case, the threshold criteria were developed for the period prior to the construction of the ICS. The use of threshold criteria to predict breakup ice jams is one of a number of breakup ice jam prediction methods (White 2003). The threshold criteria were then applied to the entire data set to "predict" breakup ice jams that would have been potentially significant in the post-ICS time period.

\footnotetext{
* The pre-ICS period is defined as the years between the disappearance of the mill dams around 1950 and ICS construction in 1981.
} 


\section{HYDROLOGICAL AND METEOROLOGICAL DATA COLLECTION}

Average daily river discharge data were obtained from the USGS. The Israel River is an ungaged river, so discharge data from the nearby Ammonoosuc River were used to best represent conditions in this watershed. The Ammonoosuc River at Bethlehem (USGS gage \#01137500) is similar in storage capacity and runoff timing to the Israel River. It has a drainage area of 87.6 square miles, compared to the drainage area of the Israel River at the confluence with the Connecticut River of 136 square miles. As in previous studies, the discharge values on the Ammonoosuc River at Bethlehem were adjusted for the Israel River using the direct drainage area transposition methods (multiplied by a ratio of the drainage areas) (e.g., Axelson 1990). The resulting plot of discharge correlates reasonably well to the actual discharge and timing of the stream based on estimated flows and observed stage levels.

Discharge data were used to predict damaging ice events. Sufficient flow is required to break up a solid ice cover and transport it downstream. However, a steady rise in flow over many days or weeks will often result in a weaker ice cover as the water scours the underside, and it usually will not cause a major event. Significant events are generally a result of a rapid rise in discharge, which breaks up a strong ice cover and jams downstream. For this evaluation, the estimated average daily discharge was used, as well as the rise in discharge at the time of the event above the calculated annual base flow. The annual base flow was estimated by averaging the 50 lowest discharge values reported for that water year. The time in days that discharge increased prior to the event is also an important factor.

Daily maximum and minimum air temperature data were obtained from National Weather Surface (NWS) meteorological stations. The NWS station in Lancaster, NH, was the primary source of temperature data. Missing data were supplemented with data from the St. Johnsbury, VT, station. To compare the long-term temperature trends, the winter-season (December through March) temperature was calculated for each year that data were available. Figure 7 shows that while winter temperatures fluctuate from year to year, the long-term trend has remained constant. 


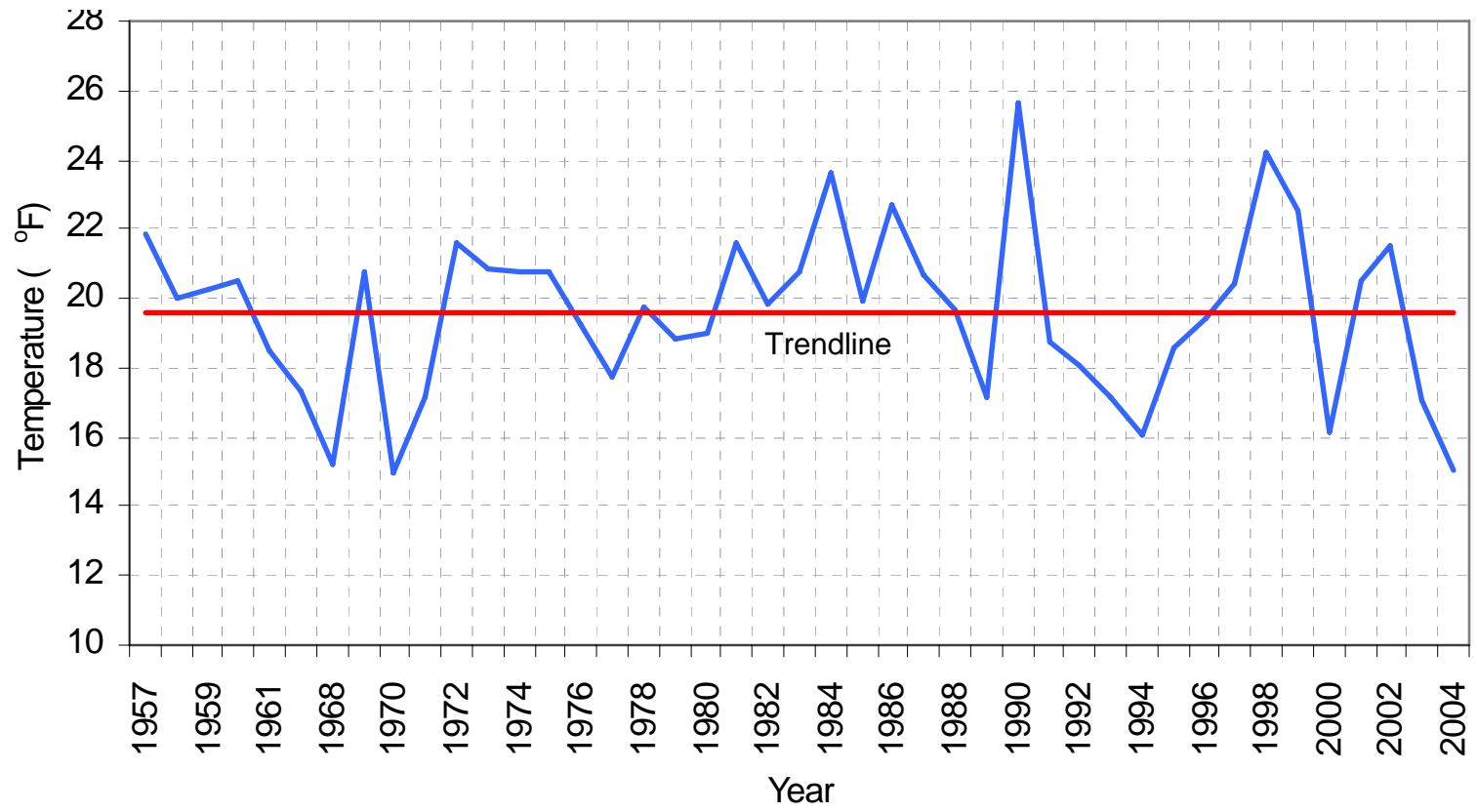

Figure 7. Average winter-season temperatures in Lancaster, $\mathrm{NH}$.

\section{Estimation of Ice Thickness}

Ice growth on a water surface is a function of heat transfer at the ice/water interface. Temperature data were used to estimate ice thickness along the Israel River based on accumulated freezing degree-days (AFDD) (White 2004). In this method, thermally induced (but not frazil) ice thickness can be estimated on a given date during the winter using temperature data for the previous months. Freezing degree-days $(F D D)$ represent the difference between the average daily air temperature $\left(T_{\mathrm{a}}\right)$ and $0^{\circ} \mathrm{F}$, where a difference in temperature below freezing is positive and above freezing is negative. The net accumulation of FDD (AFDD) over a winter season is a good indicator of winter severity. Accumulation begins in the fall when temperatures drop below freezing. AFDD can provide an estimate of ice thickness $\left(t_{\text {ice }}\right)$ in inches on a particular day using the modified Stefan equation presented in USACE (2002a):

$$
t_{\text {ice }}=C \sqrt{A F D D}
$$

where $C$ is a coefficient, usually ranging between 0.3 and 0.6 , and $A F D D$ is in ${ }^{\circ}$ F-days. A coefficient of 0.57 was determined for Lancaster based on numerous ice thickness measurements taken over the years. 
While this method provides a reasonable estimate of ice growth due to thermal processes, it is important to note that the ice thickness may be underestimated because of other factors, such as water velocity and the presence of a snow cover on top of the ice. Additionally, frazil ice deposition is known to contribute a significant amount to ice thickness in the Israel River. Figure 8 shows the estimated average ice thickness due to thermal growth for all recorded events, separated into pre- and post-ICS groups. There is no significant difference between the groups, indicating that ice conditions were the same before and after ICS construction.

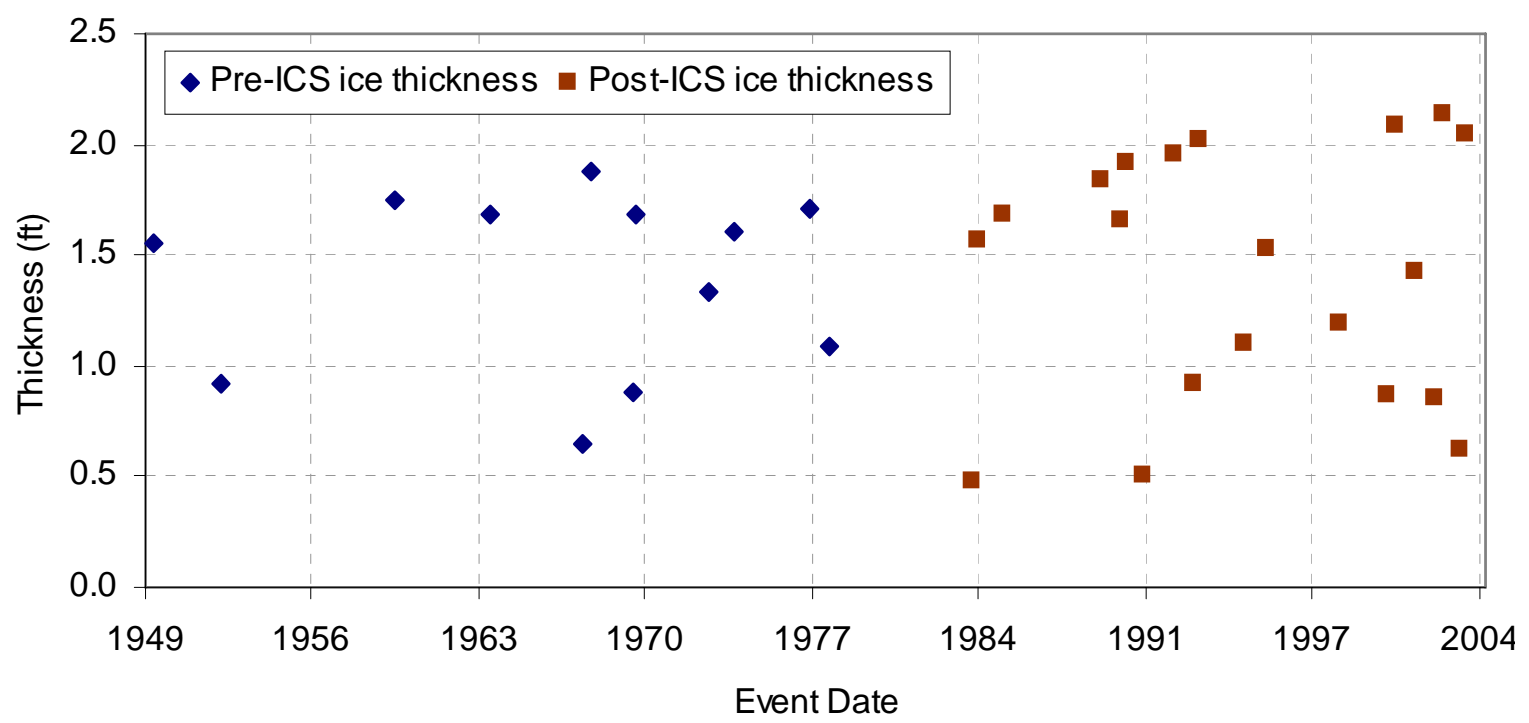

Figure 8. Estimated ice thickness for each recorded ice event in Lancaster, NH.

\section{Historical Ice Events on the Israel River at Lancaster}

Ice jams are highly localized and can be triggered by such factors as changes in river slope or configuration, bridges and other structures obstructing flow, or upstream jam releases. Temperature and discharge also contribute to ice jam formation, all of which makes jams difficult to predict without prior observations. Often historical ice event data are not readily available or reported. One reason for the underreporting of ice events involves perception stage (Gerard and Karpuk 1979), which is defined as the minimum stage at which a source will perceive an event. If an ice jam occurs but does not exceed the perception stage, most observers do not report the event. Since the construction of the ICS, ice jams at this site have been well documented. However, in the years prior to the ICS being built, it is likely that a number of smaller, non-flooding events occurred that were below perception stage and thus were not recorded. 
This study used various sources to gather ice event information on the Israel River. The CRREL Ice Jam Database (White 1996, CRREL 2005) holds over 14,000 records and is a good source of information for ice analyses. The IJDB has 33 ice jam events listed for Lancaster, NH. Various sources including project reports, trip reports, and local newspaper accounts identified four additional events.

Fifteen ice jam events were recorded prior to construction of the ICS in 1981 (Table 1). These include two major events that occurred in the late 1800s that destroyed the Main Street Bridge-a covered bridge in 1886 and an iron bridge in 1895 (W.A. Fergusson and Co. 1888). It is unclear how many dams were in place during the events of the late 1800s. The remaining jams were recorded between 1950 and 1981, after the four dams were destroyed. In 1968 the flood of record in Lancaster resulted from an ice jam event that caused water levels to rise $3 \mathrm{ft}$ above the worst open-water event. Eight other recorded ice jams caused flooding during this period, with the flood of 1953 being the next most severe.

Since construction of the ice control structure, 23 ice jams have been recorded in Lancaster (Table 2). Sixteen of the 23 jams did not cause any flooding. Four caused flooding in the police station, which was located in the basement of the town hall. Three events-March 1992, February 1996, and January 1997 (the latter two freezeup jams) — caused minor road flooding along Canal Street. There may be temporal bias because ice conditions were monitored more closely after the ICS was built than they had been before it was built. For example, a monitoring system (Williams and White 2003) has been used to record freezeup and breakup ice jam formation in Lancaster. This simple alert system monitors stages and water temperatures for use in assessing ice jam conditions by local officials.

Stage data were recorded for just six of the reported ice events. Many of the events reference the water level in the former police station, which was often flooded when a drain valve was not closed. According the Manchester Union Leader (referenced in CRREL 2005), the flood event of March 1968 resulted in 7 $\mathrm{ft}$ of water in the police station because of overbank flow, which also was reported for the flood of 1886. Stages for other events were estimated based on the 1968 reference stage, as well as USGS topographic maps. Figure 9 is a plot of the recorded ice jams and their associated stages. In this figure, ice jam events that resulted in no flooding were given an elevation of 857.5, which is the elevation of zero damage (USACE 1973). 
Table 1. Recorded ice events in Lancaster, $\mathrm{NH}$, before the completion of the ICS.

\begin{tabular}{|c|c|c|c|c|c|c|c|}
\hline Date & Description of damage & $\begin{array}{c}\text { Stage } \\
\text { (ft MSL) }\end{array}$ & $\begin{array}{l}\text { Time to } \\
\text { peak } \\
\text { (days) }\end{array}$ & $\begin{array}{l}\text { Discharge } \\
\text { (cfs) }\end{array}$ & $\begin{array}{l}\text { Change in } \\
\text { discharge } \\
\text { (cfs) }\end{array}$ & $\begin{array}{c}\text { AFDD } \\
\left({ }^{\circ} \mathrm{F} \text { days }\right)\end{array}$ & \begin{tabular}{|} 
Estimated \\
ice \\
thickness \\
(in.)
\end{tabular} \\
\hline 01 Apr 1886 & $\begin{array}{l}\text { Main St. covered bridge } \\
\text { failed; moved buildings } \\
\text { from foundations; carried } \\
\text { away fire engine }\end{array}$ & & & & & & \\
\hline 1895 & $\begin{array}{l}\text { Iron bridge failed due to } \\
\text { ice }\end{array}$ & & & & & & \\
\hline 05 Apr 1950 & & 863.8 & 2 & 3491 & 3162 & 1070.5 & 18.6 \\
\hline 25 Jan 1953 & & 858.7 & 2 & 2581 & 2465 & 379 & 11.1 \\
\hline 05 Apr 1960 & & 859.4 & 2 & 3112 & 2219 & 1362.5 & 21 \\
\hline 06 Mar 1964 & Jam toe at RR bridge & 859.5 & 2 & 2004 & 1925 & 1253.5 & 20.2 \\
\hline 13 Dec 1967 & $\begin{array}{l}\text { Jam at sharp bend; no } \\
\text { flooding }\end{array}$ & & 2 & 964 & 852 & 187 & 7.8 \\
\hline 24 Mar 1968 & $\begin{array}{l}\text { Flood of record; Major } \\
\text { flood damage: } 1.1 \mathrm{M} \text { USD } \\
\text { (1973 dollars); } 7 \mathrm{ft} \text { in } \\
\text { police station }\end{array}$ & 866.6 & 3 & 2581 & 1746 & 1572 & 22.6 \\
\hline 27 Dec 1969 & No flooding & & 1 & 3188 & 3051 & 343.5 & 10.6 \\
\hline 11 Feb 1970 & $\begin{array}{l}\text { Flooding, bridges closed; } \\
\text { windows broken by ice }\end{array}$ & 863.3 & 1 & 3476 & 3224 & 1253.5 & 20.2 \\
\hline 23 Jan 1973 & $\begin{array}{l}\text { Flooding } 2 \mathrm{ft} \text { in police } \\
\text { station }\end{array}$ & $861.6^{*}$ & 2 & 911 & 516 & 786 & 16 \\
\hline 05 Mar 1974 & $\begin{array}{l}\text { Police station flooded; } \\
\text { road flooding }\end{array}$ & $859.6^{*}$ & 1 & 1518 & 1328 & 1142.5 & 19.3 \\
\hline 31 Mar 1977 & $\begin{array}{l}\text { Flooding in police station } \\
\text { (6 in.) }\end{array}$ & $860.1^{*}$ & 3 & 3021 & 2782 & 1293 & 20.5 \\
\hline 09 Jan 1978 & & unkn. & 2 & 2277 & 2177 & 519 & 13 \\
\hline Jan 1980 & No flooding & & & & & & 0 \\
\hline
\end{tabular}

* Stage estimated from level of flooding in police station. 
Table 2. Recorded ice events in Lancaster, $\mathrm{NH}$, after the completion of the ICS.

\begin{tabular}{|c|c|c|c|c|c|c|c|}
\hline Date & Description of damage & $\begin{array}{c}\text { Stage } \\
(\mathrm{ft} \text { MSL) }\end{array}$ & $\begin{array}{l}\text { Time to } \\
\text { peak } \\
\text { (days) }\end{array}$ & $\begin{array}{c}\text { Discharge } \\
\text { (cfs) }\end{array}$ & $\begin{array}{l}\text { Change in } \\
\text { discharge } \\
\text { (cfs) }\end{array}$ & $\begin{array}{c}\text { AFDD } \\
\left.\text { ( }{ }^{\circ} \mathrm{F} \text { days }\right)\end{array}$ & $\begin{array}{l}\text { Estimated } \\
\text { ice } \\
\text { thickness } \\
\text { (in.) }\end{array}$ \\
\hline 14 Dec 1983 & No flooding & & 2 & 2899 & 2663 & 100.5 & 5.7 \\
\hline 20 Feb 1984 & Flooding in police station & $859.6^{*}$ & 1 & 1655 & 1214 & 1096.5 & 18.9 \\
\hline Dec 1984 & No flooding & & & & & & \\
\hline 25 Feb 1985 & No flooding & & 2 & 1548 & 1321 & 1251.5 & 20.2 \\
\hline 28 Mar 1989 & $\begin{array}{l}\text { Ice held above weir until } \\
29 \text { Mar }\end{array}$ & & 2 & 2459 & 2180 & 1497.5 & 22.1 \\
\hline 26 Jan 1990 & Ice held above weir & & 1 & 577 & 437 & 1209 & 19.8 \\
\hline 17 Mar 1990 & Flooding in police station & $859.6^{*}$ & 3 & 3537 & 2869 & 1636.5 & 23.1 \\
\hline 23 Dec 1990 & Flooding in police station & $859.6^{*}$ & 2 & 2581 & 2266 & 112 & 6 \\
\hline 11 Mar 1992 & $\begin{array}{l}\text { Minor flooding; jam in } \\
\text { place about } 4 \text { hours }\end{array}$ & $858.5^{\star}$ & 1 & 3537 & 2869 & 1694.5 & 23.5 \\
\hline 05 Jan 1993 & No flooding & & 1 & 607 & 471 & 374.5 & 11 \\
\hline 29 Mar 1993 & $\begin{array}{l}\text { Jam at Main St. bridge; } \\
\text { no flooding }\end{array}$ & & 2 & 531 & 410 & 1813 & 24.3 \\
\hline 16 Jan 1995 & Flooding in police station & $859.6^{\star}$ & 2 & 1123 & 941 & 539 & 13.2 \\
\hline 20 Jan 1996 & $\begin{array}{l}\text { Flooding, property } \\
\text { damage and street } \\
\text { closings; water } 2 \mathrm{ft} \text { above } \\
\text { Canal St. }\end{array}$ & $860.5^{\star}$ & 3 & 4250 & 4150 & 1034.5 & 18.3 \\
\hline Jan 1997 & $\begin{array}{l}\text { Flooding along Canal St. } \\
\text { and Water St. }\end{array}$ & $858.5^{\star}$ & & & & & \\
\hline 24 Jan 1999 & $\begin{array}{l}\text { Ice piled on Rt. } 3 \text { bridge; } \\
\text { no flooding }\end{array}$ & & 1 & 2581 & 2332 & 629.5 & 14.3 \\
\hline 17 Dec 2000 & $\begin{array}{l}\text { Ice } 2 \mathrm{ft} \text { from low chord of } \\
\text { bridge; no flooding }\end{array}$ & & 1 & 2732 & 2602 & 330.5 & 10.4 \\
\hline 13 Apr 2001 & $\begin{array}{l}\text { Ice touched the low chord } \\
\text { of the bridge; no flooding }\end{array}$ & & 2 & 744 & 455 & 1936 & 25.1 \\
\hline 04 Mar 2002 & Mild winter & & 2 & 501 & 357 & 904 & 17.1 \\
\hline 21 Dec 2002 & $\begin{array}{l}\text { Jam at covered bridge; } \\
\text { no flooding }\end{array}$ & & 2 & 691 & 524 & 325.5 & 10.3 \\
\hline 22 Mar 2003 & $\begin{array}{l}\text { Jam downstream of Main } \\
\text { St. bridge; no flooding }\end{array}$ & & 2 & 622 & 505 & 2015 & 25.6 \\
\hline 12 Dec 2003 & $\begin{array}{l}\text { Webcam reported jam; } \\
\text { no flooding }\end{array}$ & & 2 & 2064 & 1820 & 173.5 & 7.5 \\
\hline 27 Mar 04 & $\begin{array}{l}\text { Webcam reported jam; } \\
\text { no flooding }\end{array}$ & & 2 & 805 & 713 & 1862 & 24.6 \\
\hline 31 Mar 05 & $\begin{array}{l}\text { Ice jam upstream of the } \\
\text { Rt } 3 \text { bridge; no flooding }\end{array}$ & & & & & 1710.5 & 23.6 \\
\hline
\end{tabular}




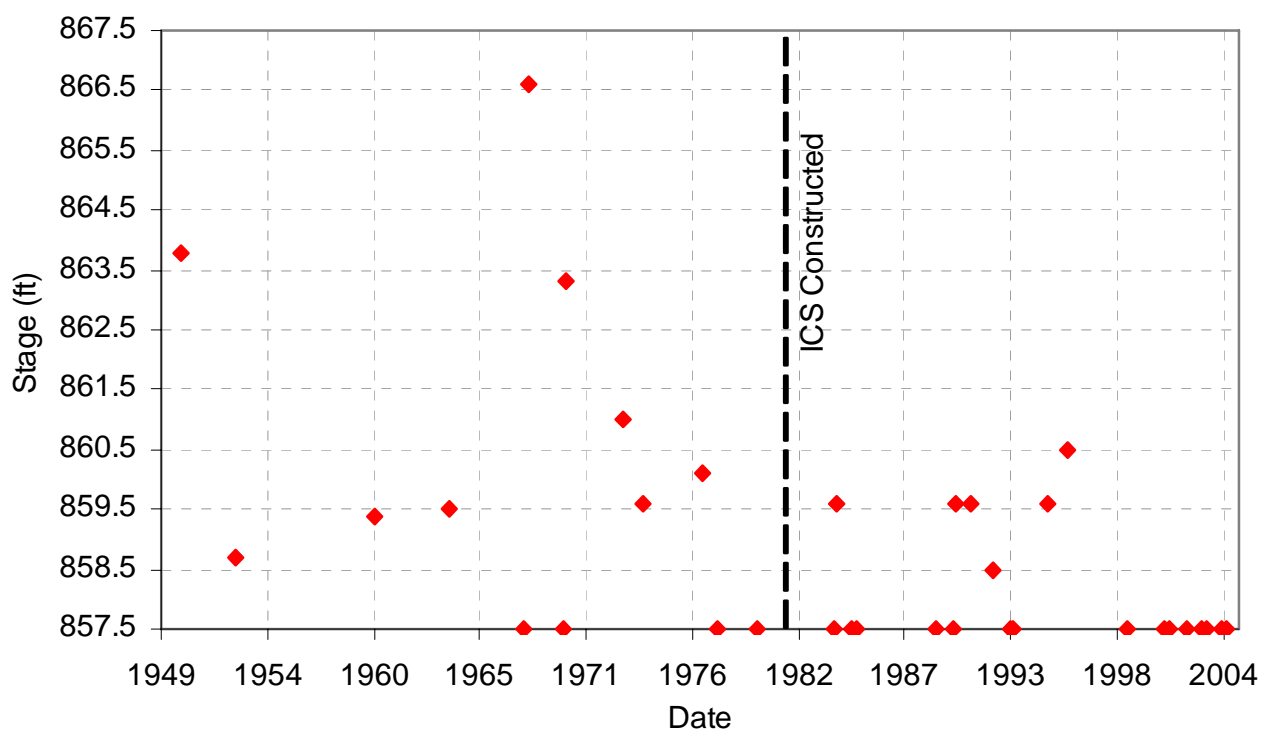

Figure 9. Recorded or estimated stages for Lancaster, NH, ice events. 


\section{ICE JAM CRITERIA}

Ice jams recorded prior to the construction of the ICS were reviewed in an attempt to understand the conditions likely to cause significant flooding due to a breakup ice event. Criteria were developed based on the five jams with the highest recorded stages $(1968,1950,1970,1973$, and 1977) and applied to post-ICS data. The physical variables used in the threshold criteria were the estimated ice thickness at the time of the event, the estimated discharge, and the change in temperature and discharge in the days leading up to the event. Similar criteria were used by Tuthill et al. (1996) to synthesize ice records for the Winooski River. The following severe breakup ice jam initiation criteria were established for the Israel River at Lancaster:

- Ice thickness greater than 17 in. at the time of breakup;

- Discharge of at least $1700 \mathrm{cfs}$ more than the annual base flow at the time of the event;

- Flow increasing at the time of breakup, but not for more than three days prior to breakup (i.e., rapid rise in discharge);

- Temperatures that increased in the few days just prior to the jam but were not above freezing for an entire 10 days leading up to the jam (melt out); and

- No ice breakup 30 days prior to the jam (i.e., no discharge greater than $1000 \mathrm{cfs})$.

These criteria were applied to data for the entire period of record to hindcast severe breakup ice jams during the period before the ICS was built and to predict severe breakup ice jams in the period after the ICS was built. In this case, severe ice jam events are those that cause damaging floods. Since the construction of the ICS, no damaging floods have occurred in Lancaster, so any predicted in the analysis were assumed to have been prevented by the structure.

Fourteen significant ice jams were predicted for 1946-2004, including the five used to determine the criteria (Table 3). Two additional jams were predicted prior to the construction of the ICS that were not identified during the historical review (1954 and 1959). It is possible that a concentrated search of records for 1954 and 1959 would reveal these events. However, to date, such a search has not been made. The 1981 event occurred during construction of the ICS, which did provide some ice retention although it was not yet complete (Fig. 10). The ice retention during this event could have prevented a significant jam in town, so a conditional "yes" is assigned in Table 3. Based on these results, the threshold criteria are considered adequate to predict severe breakup jamming in Lancaster. 
Table 3. Significant ice jam events predicted in Lancaster, NH.

\begin{tabular}{|c|c|c|c|c|c|c|c|}
\hline Event date & $\begin{array}{c}\text { AFDD } \\
\left({ }^{\circ} \mathrm{F} \text { days }\right)\end{array}$ & $\begin{array}{c}\text { Ice } \\
\text { thickness } \\
\text { (in.) }\end{array}$ & $\begin{array}{c}\text { Time to } \\
\text { peak } \\
\text { (days) }\end{array}$ & $\begin{array}{l}\text { Average } \\
\text { daily flow } \\
\text { (cfs) }\end{array}$ & $\begin{array}{c}\text { Base flow } \\
\text { (cfs) }\end{array}$ & $\begin{array}{l}\text { Change in } \\
\text { discharge } \\
\text { (cfs) }\end{array}$ & $\begin{array}{l}\text { Recorded } \\
\text { ice event }\end{array}$ \\
\hline 5 Apr 1950 & 1326 & 20.76 & 2 & 3491.4 & 102.4 & 3389.0 & yes \\
\hline 8 Apr 1954 & 1174.5 & 19.53 & 2 & 2595.8 & 84.9 & 2510.9 & \\
\hline 3 Apr 1959 & 2004.5 & 25.52 & 2 & 2580.6 & 69.0 & 2511.6 & \\
\hline 31 Mar 1960 & 1475 & 21.89 & 1 & 2808.3 & 92.0 & 2716.3 & yes \\
\hline 5 Mar 1964 & 1331.5 & 20.80 & 1 & 1897.5 & 85.8 & 1811.7 & yes \\
\hline 23 Mar 1968 & 1754.5 & 23.88 & 2 & 1973.4 & 78.5 & 1894.9 & yes \\
\hline 11 Feb 1970 & 1317 & 20.69 & 1 & 3476.2 & 126.3 & 3349.9 & yes \\
\hline 12 Feb 1981 & 1634 & 23.04 & 2 & 3491.4 & 97.5 & 3393.9 & (yes) \\
\hline 29 Mar 1989 & 1638 & 23.07 & 2 & 2459.2 & 64.1 & 2395.1 & yes \\
\hline 16 Mar 1990 & 1779.5 & 24.04 & 3 & 2064.5 & 116.1 & 1948.4 & yes \\
\hline 11 Mar 1992 & 1791.5 & 24.13 & 1 & 3536.9 & 99.5 & 3437.5 & yes \\
\hline 19 Jan 1996 & 1091.5 & 18.83 & 1 & 3036.0 & 96.5 & 2939.5 & yes \\
\hline 10 Mar 2002 & 1012 & 18.13 & 1 & 1912.7 & 86.6 & 1826.0 & \\
\hline 2 Apr 2004 & 1987 & 25.41 & 2 & 1806.4 & 95.6 & 1710.9 & \\
\hline
\end{tabular}

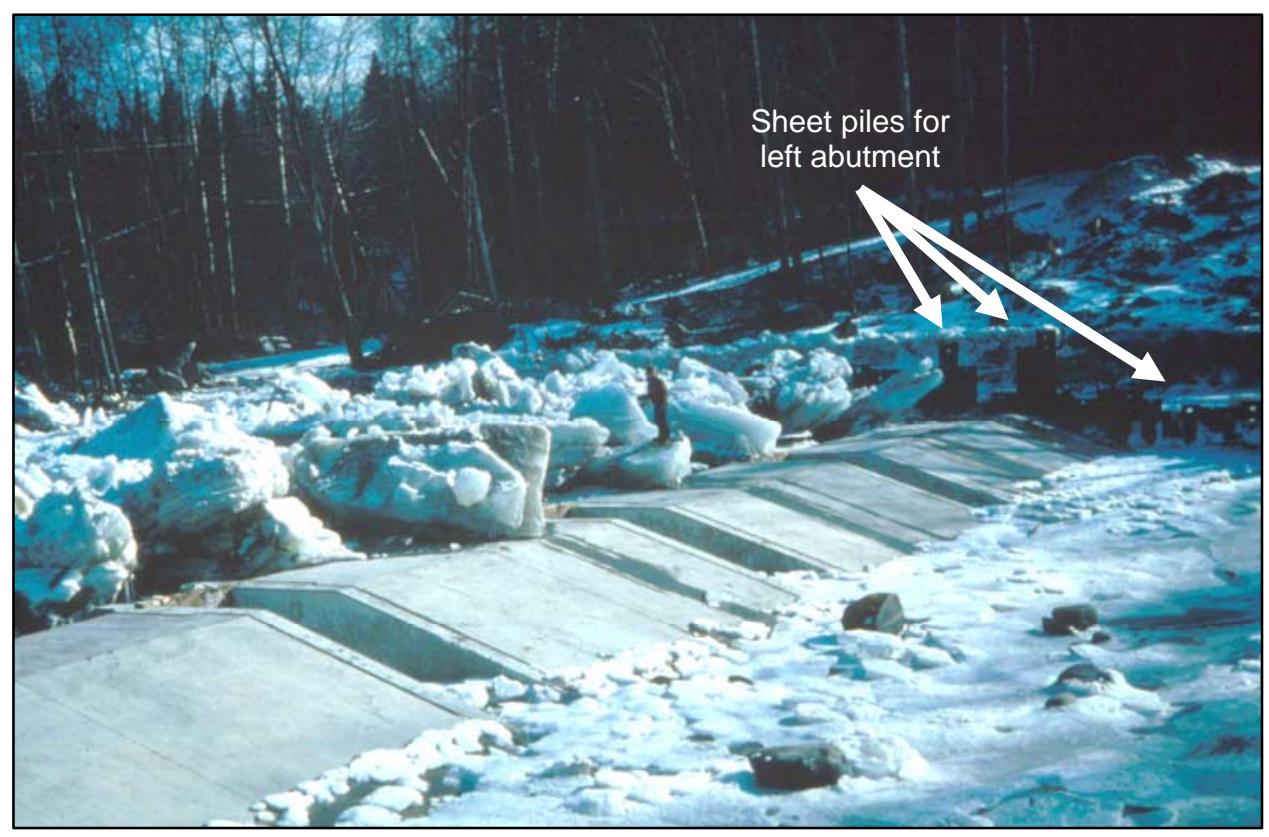

Figure 10. Ice retention upstream from the ICS during construction, winter 1980-81. 
After the construction of the ICS, six severe jams were predicted, four of which are recorded ice events at Lancaster (1989, 1990, 1992, and 1996), though none caused significant flooding. CRREL field notes from March 1989 indicate that the 1989 ice jam extended from the abandoned railroad abutments to the covered bridge and that upstream ice was held above the ICS. CRREL field notes from March 1990 report that the jammed ice reached the bottom of the temporary bridge that spanned the river upstream from the Main Street Bridge during the winter of 1989-90. In 1992, Coos Magazine (1992) printed photographs of the ice jammed at the Main Street Bridge, which was briefly closed. During this event, ice also held above the weir (Fig. 3). A CRREL trip report, dated 12 March 1992, noted large blocks of ice piled up on the left edge of the weir, indicating that the ICS caused some type of jam before releasing. Discussions with the town manager, Amy Lehman, revealed that the jam occurred in the early afternoon on the $11^{\text {th }}$, piling against the Main Street Bridge. At 1800 hours, a surge from upstream, likely the release of the jam above the ICS, caused the downtown jam to go out. The 20-21 January 1996 event was a very high discharge event throughout New England that resulted when a substantial snowpack melted rapidly because of a combination of precipitation, unseasonablely warm temperatures, and windy conditions. Ice jammed briefly at Lancaster, but CRREL field notes indicate that the water levels were very high and much of the ice had disappeared.

Two jams were identified as being potentially severe after the ICS was in place, but were not. In 2002, an ice jam occurred on 4 March, about a week before the predicted jam shown in Table 3. Ice was retained above the ICS. That year, the ice was thought to be weaker and thinner than predicted by the Stefan equation because of a melt event recorded on 12 February. This allowed breakup to occur at a lower discharge than normal, and, while causing a relatively high stage (Fig. 11), the jam remained in place only for a matter of hours. Thus, the larger flow identified in Table 3 occurred during open-water conditions on the Israel River in Lancaster. In the spring of 2004, a smaller jam was recorded by the monitoring equipment on 27 March, about a week prior to the event predicted by the threshold criteria. The jam caused a stage increase of about $4 \mathrm{ft}$ at the measuring site, and it remained in place until 30 March, with a little shove on 29 March. 


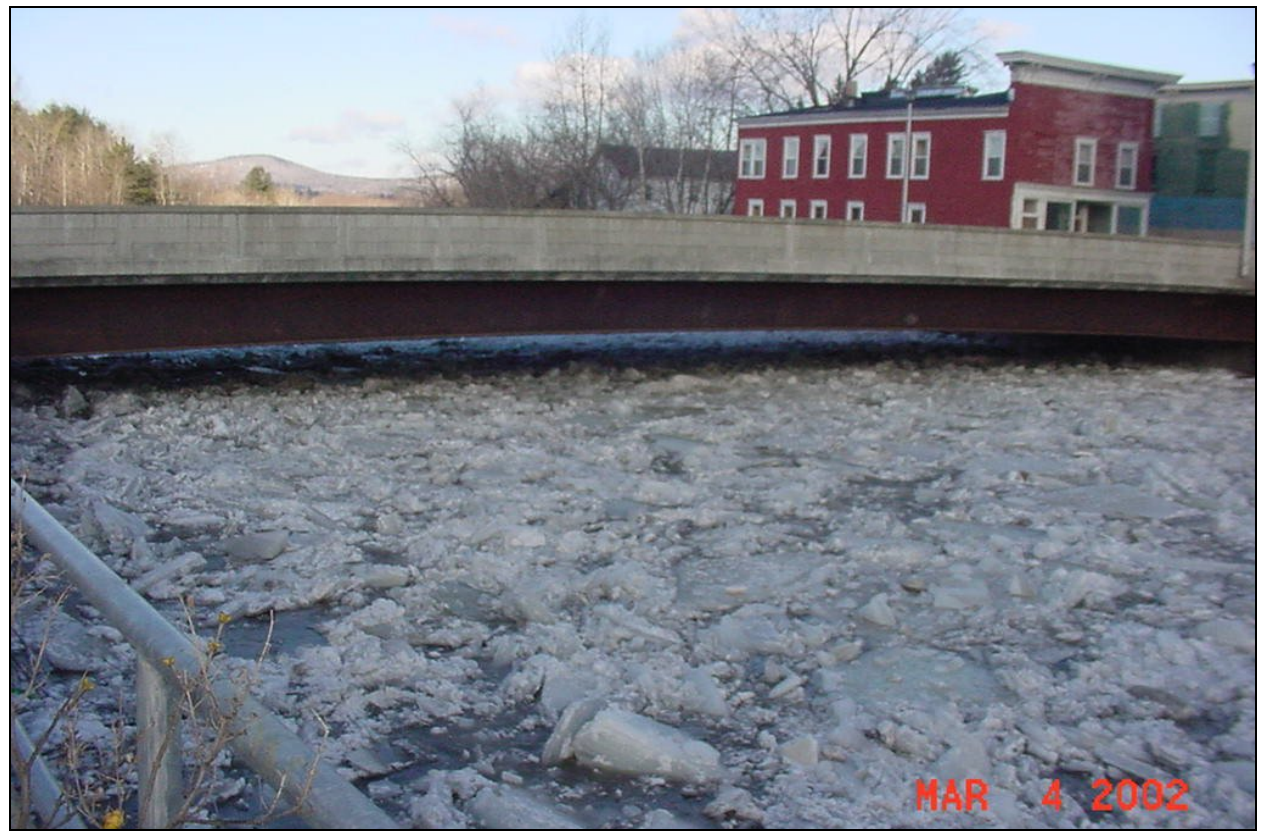

Figure 11. Ice jam of 4 March 2002 (looking downstream toward the Main Street Bridge). 


\section{IMPLICATIONS OF REBUILT MAIN STREET BRIDGE}

It has recently been suggested that the damaging ice jams in the past were actually caused by the double-arch Main Street Bridge (Fig. 12) and that its replacement in 1989-90 with the single-span bridge seen in Figure 11 has resulted in decreased jam severity. Alternatively, some have suggested that the double-arch configuration of the previous Main Street Bridge increased the severity of ice jams in the reach of the Israel River above Main Street.

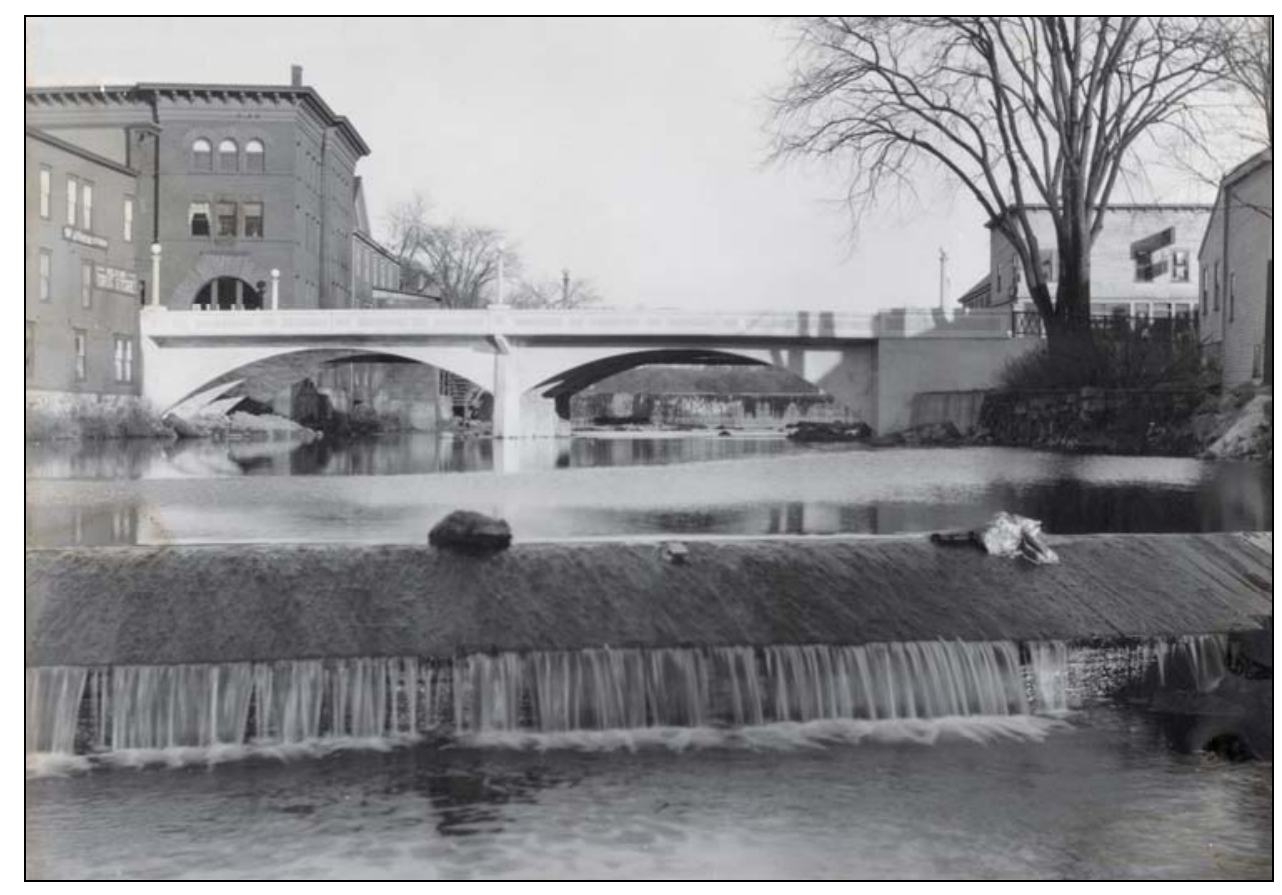

Figure 12. Double-arch Main St. Bridge circa 1928, replaced in 1989-90. Dams \#131.01 and 131.02 are visible in the foreground and background, respectively. (Photo courtesy Town of Lancaster.)

The current Main Street Bridge in Lancaster is the latest in a series of bridges in about the same location. All of the bridges impact conveyance in some manner or another as the jamming ice fills the bridge openings. As noted earlier, two previous bridges at the same location-a covered bridge in 1886 and an iron bridge in 1895-were destroyed by ice events (W.A. Fergusson and Co. 1888). As ice jams progressed up through the double-arch Main Street Bridge, they often reached nearly to the top of the arches. Figure 13, taken during the March 1968 ice event, shows that ice was within a foot of so of the top of the arch on the 


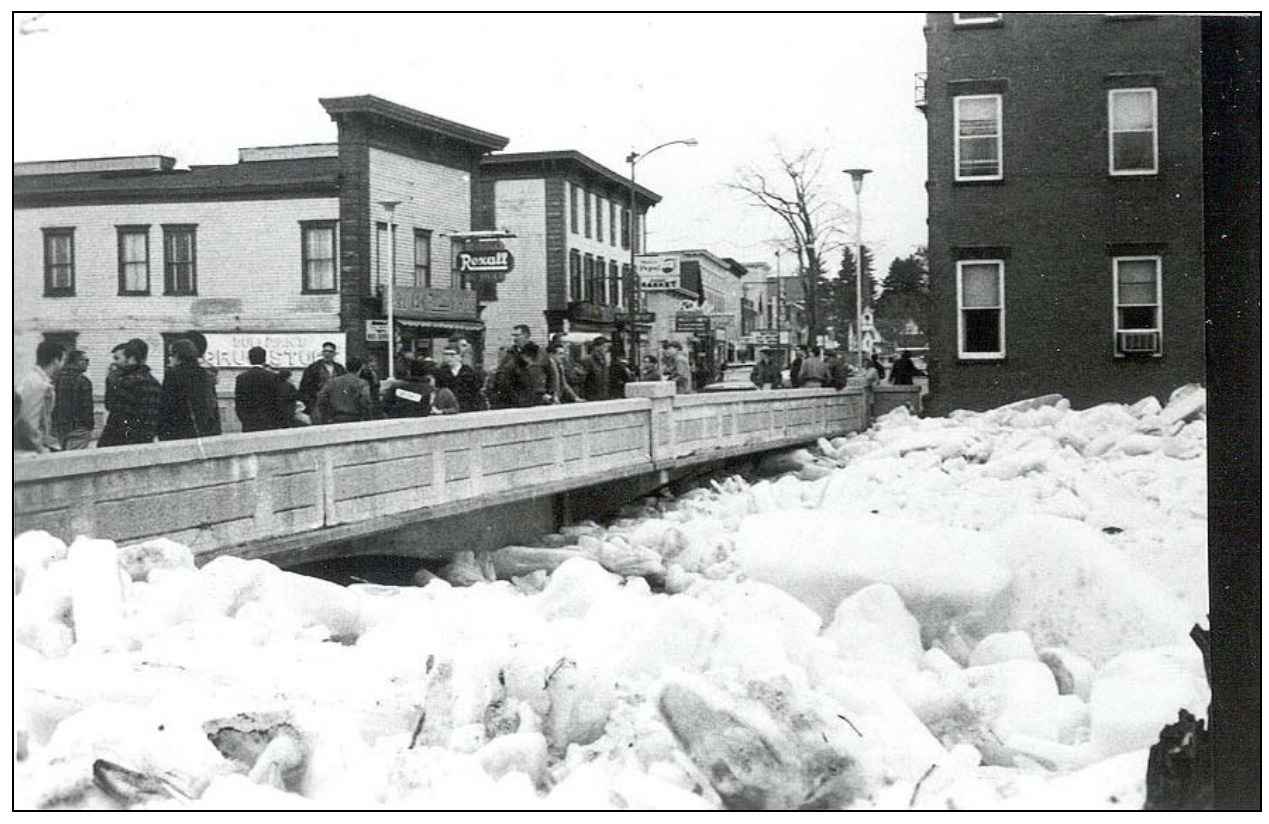

a. Upstream face.

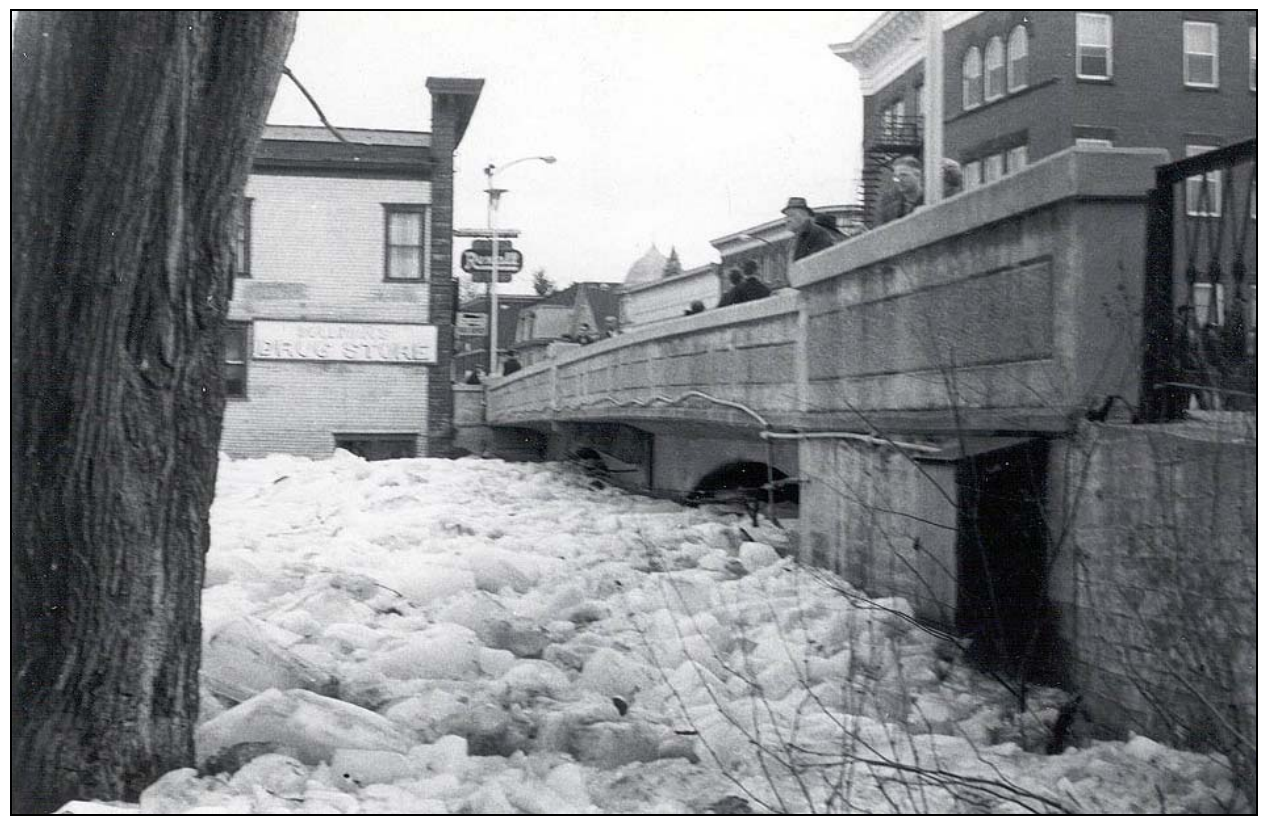

b. Downstream face.

Figure 13. The Main Street Bridge during the March 1968 ice jam. 
downstream side of the bridge and was piling up against the upstream side of the bridge. The same process occurs with the single-span bridge, and similar pileups occur at the upstream face of this bridge (e.g., Fig. 14 and 15). Local residents reported standing on the bridge and reaching out to touch the ice (even with the handrail) on the upstream side of the bridge.

Regarding the first suggestion (that the double-arch bridge caused the ice jams), ample evidence exists that the primary cause of the ice jams, both freezeup and breakup, is the reduction in conveyance associated with the change in slope that occurs when the Israel River meets the backwater effects of the Connecticut River. Numerous observers have reported that the ice jam begins near the abandoned railroad abutments and then progresses upstream through the Main Street Bridge. For example, Frankenstein and Denhartog (1969) observed that "The river, which flows through the center of Lancaster, was open upstream from a few feet below the Main Street Bridge, but full of broken pieces, or jammed from there downstream about 2,000 ft to an old abandoned railroad abutment. Below this the river was again open.” This description is especially useful in pinpointing the source of the jamming as the change in conveyance, because open water existed downstream from the jam.

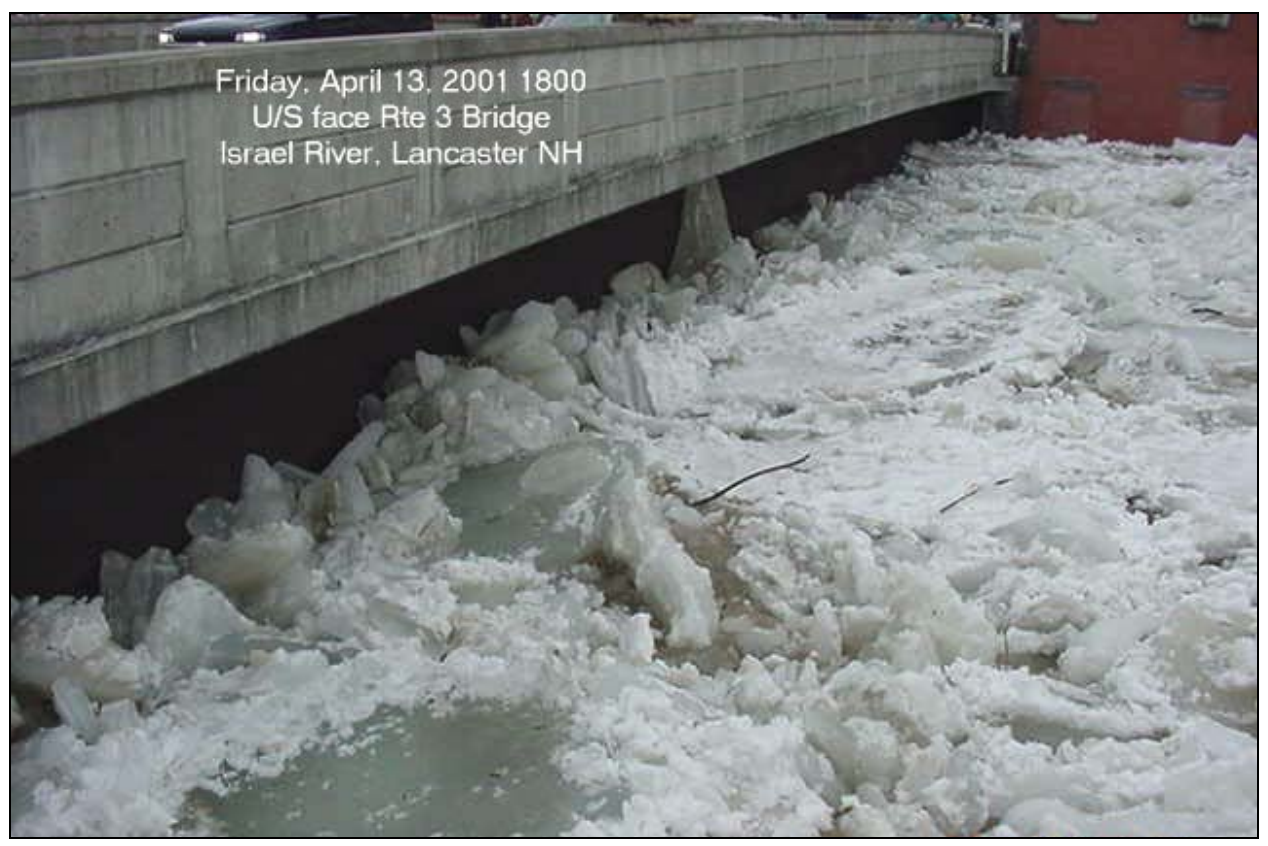

Figure 14. Ice building up on the upstream face of the single-span Main Street Bridge in April 2001. (From USA CRREL Ice Jam Database.) 


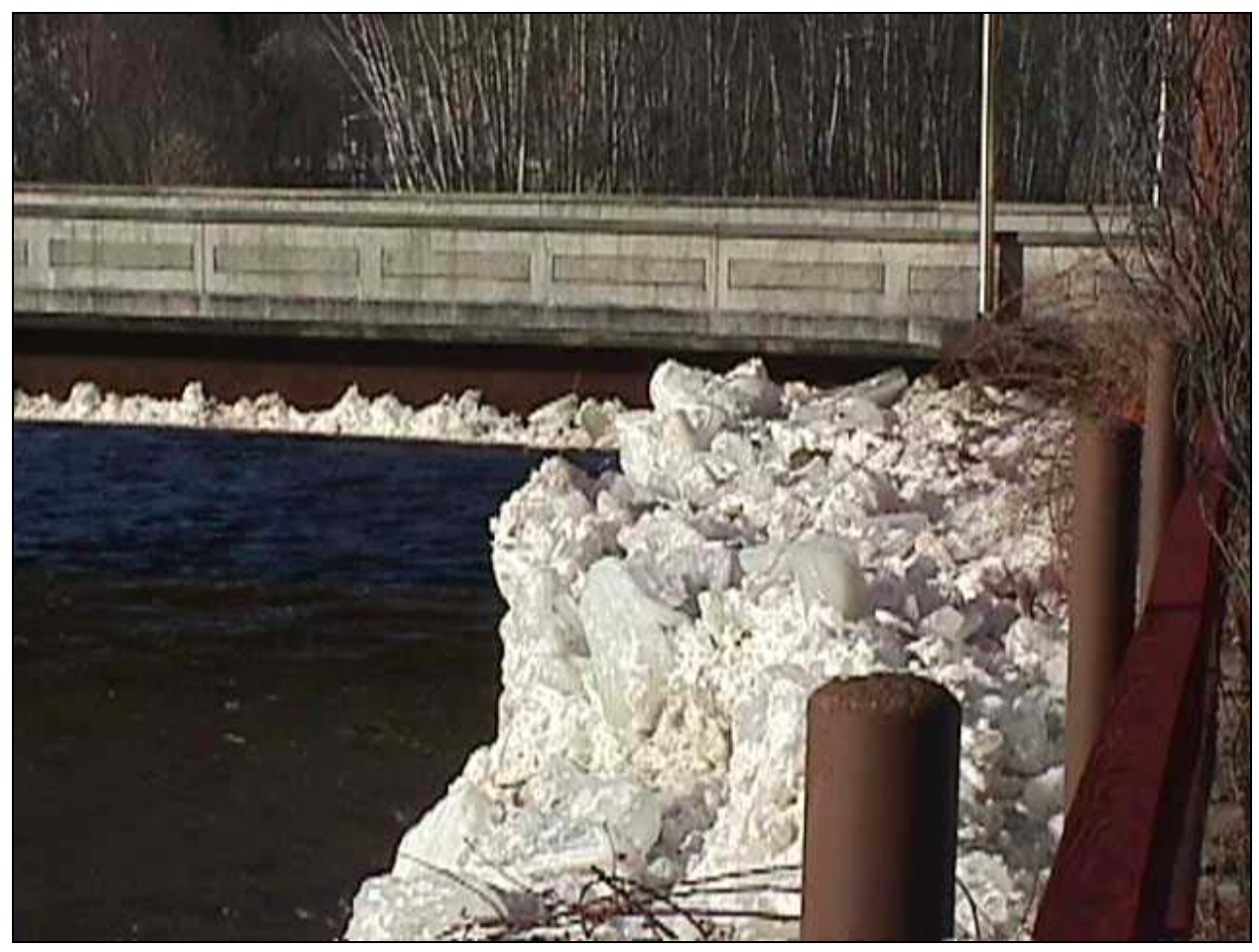

Figure 15. Upstream view of the Main Street Bridge after the ice jam of January 1999. (Photo courtesy of Greatnorthwoods.org, http://www. greatnorthwoods.org/lancaster/icejam19990124/1/.)

Regarding the second suggestion (that replacing the double-arch configuration of the Main Street Bridge with a single span is the primary reason for the decrease in severe ice jams in Lancaster), an examination of the ice regime in the winter seasons before the double-arch bridge was replaced but after construction of the ICS is required. If severe jams were predicted during this period but did not actually occur, we assume that the ICS played a primary role in decreasing the severity compared to events with similar conditions that occurred prior to the ICS construction.

During this period, which spans 1981 through 1990, Table 3 predicts three severe ice jams: in 1981, 1989, and 1990. In 1981, significant amounts of ice were retained upstream from the ICS (Fig. 10). As noted previously, field notes report significant volumes of jammed ice in the river extending as far up as the covered bridge. At the same time, the ICS retained ice from upstream. If this ice had not been retained, it would have pushed downstream and added to the volume of ice already jammed, thickening the jam, possibly to similar proportions as in 1968, 1950, and 1970. Ice was reported jammed up to the covered bridge in the 1989 event, and that upstream ice was held above the ICS. In 1990 
the jam did not extend as far upstream, but it was thick enough to reach the bottom of the temporary bridge used during construction of the new bridge. Although these jams did occur, they were not severe damaging jams, suggesting that the ICS is the primary reason for decreased severity of ice jams.

Four severe events were predicted after the bridge was replaced, in 1992, 1996, 2002, and 2004. Conditions at the time of the latter two predicted events were discussed previously. The 1996 flood had the fifth highest stage on record and the highest recorded since the construction of the ICS. This experience indicates that although the removal of the center pier and the associated decrease in wetted perimeter has resulted in some increased conveyance through the bridge, the changed configuration of the bridge has not reduced the jam conditions. This fact is confirmed by numerous instances when the ice has built up on the upstream face of the low steel of the single-span bridge (e.g., 1992, 1996, 1999, 2001, 2003, and 2006). 


\section{CONCLUSIONS}

Based on this initial investigation, it appears that the Israel River ICS provides some relief from major ice jam flooding. Conditions that led to major ice events between 1950 and 1981 have not moderated in recent years. Average winter temperatures and ice thicknesses at the time of events have remained consistent. Monitoring has shown that the ICS provides some frazil ice retention in addition to breakup ice retention. Threshold criteria characterizing severe breakup ice jam events prior to the completion of the ICS were used to evaluate the likelihood of jamming after the construction of the ICS. Winter conditions that led to severe ice jam flooding in the past have occurred during four of the ice jams recorded since the ICS was constructed, though no major flooding has taken place in Lancaster during this period.

The results of this preliminary analysis indicate that the Israel River ICS does provide some flood damage reduction benefit to the Town of Lancaster. 


\section{RECOMMENDATIONS FOR FURTHER STUDY}

Further analysis could quantify the benefits of the Israel River ICS. A hydrologic model, such as HEC-HMS (Ford et al. 2002), could be used to synthesize flows at Lancaster with meteorological data. The model could be calibrated to the stage gage installed downstream of the Route 2 bridge in December 2002, although a more permanent installation at the bridge is recommended. This would eliminate the need to rely on data from another watershed to estimate daily flows.

Ice-affected flood stages could be determined by developing a hydraulic model of the Israel River using HEC-RAS (USACE 2002b). The model will be calibrated to open-water conditions using the 1973 Flood Insurance Study (FEMA 1973) and to ice-affected conditions using the pre-ICS events with detailed stage information. Verification of cross-sectional information, including both bridges, will be required for an updated HEC-RAS model. To determine how effective the ice control structure is at reducing flood levels, the post-ICS events will be run with and without the structure in place and compared. 


\section{REFERENCES}

Coos Magazine (1992) Ice and water create more anxious hours. April, p. 16-17.

Axelson, K.D. (1989) Israel River Ice Control Structure field study interim report. Internal Report No. 1038, U.S. Army Cold Regions Research and Engineering Laboratory, Hanover, New Hampshire.

Axelson, K.D. (1990) Israel River Ice Control Structure interim report. Internal Report 1065, U.S. Army Cold Regions Research and Engineering Laboratory, Hanover, New Hampshire.

CRREL (2005) CRREL ice jam database. U.S. Army Cold Regions Research and Engineering Laboratory, Hanover, New Hampshire. http://www.crrel.usace. army.mil/ierd/ijdb/. Accessed August 2005.

Federal Emergency Management Agency (1973) Flood insurance study, Town of Lancaster, NH. Prepared by U.S. Department of Agriculture Soil Conservation Service.

Ford, D., N. Pingel, and J.J. DeVries (2002) Hydrologic modeling system HEC-HMS. HEC Report CPD 74C, Applications Guide, U.S. Army Corps of Engineers Hydrologic Engineering Center, Davis, California. http://www.hec. usace.army.mil/software/hec-hms/documentation/hms_technical.pdf

Frankenstein, G.E., and S.L. Denhartog (1969) Ice conditions on the Israel River, Lancaster, NH. Unpublished USA Contract Report, U.S. Army Cold Regions Research and Engineering Laboratory, Hanover, New Hampshire, 30 December.

Gerard, R.L., and E.W. Karpuk (1979) Probability analysis of historical flood data. Journal of the Hydraulics Division, ASCE, 105(HY9): 1153-1165.

Provan and Lorber, Inc. (2003) Final report, Israel River Ice Control Structure, Lancaster, NH. Report prepared for the Town of Lancaster, New Hampshire.

Tuthill, A.M., J.L. Wuebben, S.F. Daly, and K.D. White (1996) Probability distributions for peak stage on rivers affected by ice jams. ASCE, Journal of Cold Regions Engineering, 10(1): 36-57.

Tuthill, A.M., C. M. Vuyovich, and K.D. White (2003) Ice-affected stagefrequency development along the Connecticut River. Proceedings, 12th Workshop on the Hydraulics of Ice Covered Rivers, Edmonton, Alberta, Canada, June 19-20, 2003.

USACE (1964) Letter report on Israel River, Connecticut River Basin, Lancaster, New Hampshire. Unpublished report, U.S. Army Corps of Engineers, June. 
USACE (1973) Lancaster local flood protection - Detailed project report. U.S. Army Corps of Engineers, New England Division, Waltham, Massachusetts.

USACE (1974) Technical memorandum: Control of ice jams at Lancaster, NH. Unpublished report, U.S. Army Corps of Engineers, August.

USACE (1978) Lancaster, NH, local ice-jam flood control project, Israel River, Revised supplement to the DPR. U.S. Army Corps of Engineers, New England Division, Waltham, Massachusetts.

USACE (1982) Lancaster, NH, Israel River operation and maintenance manual. U.S. Army Corps of Engineers, New England Division, Waltham, Massachusetts.

USACE (2002a) Engineering and Design - Ice Engineering. U.S. Army Corps of Engineers Engineer Manual 1110-2-1612, http://www.usace.army.mil/inet/usacedocs/eng-manuals/em1110-2-1612/toc.htm.

USACE (2002b) HEC-RAS River Analysis System user's manual, Version 3.1. HEC Report CPD 68, U.S. Army Corps of Engineers Hydrologic Engineering Center, Davis, California. http://www.hec.usace.army.mil/software/hec-ras/ documents/userman/index.html

USGS (2004) Real-time water data for USGS 01011000, Allagash River near Allagash, ME. U.S. Geological Survey. http://waterdata.usgs.gov/usa/nwis/uv? site_no=01011000. Accessed April 17, 2004.

Vuyovich, C.M., A.M. Tuthill, S.F. Daly, and K.D. White (2005) Ice impact evaluation for the Lower Connecticut River map modernization, Hampden County, MA, and Hartford and Middlesex Counties, CT. Report prepared for the Federal Emergency Management Agency, Region 1, May. U.S. Army Engineer Research and Development Center, Cold Regions Research and Engineering Laboratory, Hanover, New Hampshire.

W.A. Fergusson and Co. (1888) The History of Coos County. Reprinted 1972. Somersworth, New Hampshire: NH Publishing Co.

Williams, C.R., and K.D. White (2003) Early warning flood stage monitoring equipment. ERDC Technical Note 03-2, April, U.S. Army Engineer Research and Development Center, Cold Regions Research and Engineering Laboratory, Hanover, New Hampshire. http://www.crrel.usace.army.mil/ierd/tectran/ ieieb.htm.

White, K.D. (1996) A new ice jam database. Journal of the American Water Resources Association, 32(2): 341-348.

White, K.D. (2003) Review of prediction methods for breakup ice jams. Canadian Journal of Civil Engineering, 30(1): 89-100. 
White, K.D. (2004) Method to estimate river ice thickness based on meteorological data.” ERDC/CRREL Technical Note 04-3, U.S. Army Engineer Research and Development Center, Cold Regions Research and Engineering Laboratory, Hanover, New Hampshire. http://www.crrel.usace.army.mil/ techpub/CRREL_Reports/reports/TN04-3.pdf.

White, K.D., and J.N. Moore (2002) Impacts of dam removal on riverine ice regime. ASCE, Journal of Cold Regions Engineering, 16(1): 2-16. 


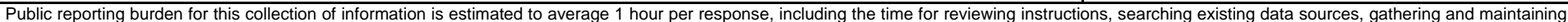

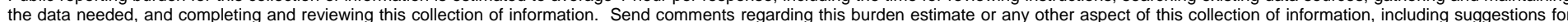

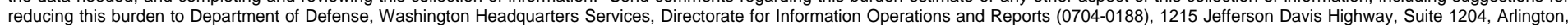

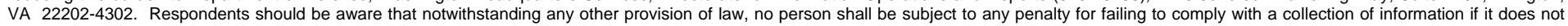
display a currently valid OMB control number. PLEASE DO NOT RETURN YOUR FORM TO THE ABOVE ADDRESS.

\begin{tabular}{l|l}
\hline 1. REPORT DATE (DD-MM-YYYY) & $\begin{array}{l}\text { 2. REPORT TYPE } \\
\text { January } 2006\end{array}$ \\
Technical Report
\end{tabular}

\section{TITLE AND SUBTITLE}

Technical Report

3. DATES COVERED (From - To)

Assessment of the Effectiveness of the Israel River Ice Control Structure, Lancaster, NH

5a. CONTRACT NUMBER

5b. GRANT NUMBER

5c. PROGRAM ELEMENT NUMBER

6. AUTHOR(S)

5d. PROJECT NUMBER

Carrie M. Vuyovich and Kathleen D. White

5e. TASK NUMBER

5f. WORK UNIT NUMBER

7. PERFORMING ORGANIZATION NAME(S) AND ADDRESS(ES)

8. PERFORMING ORGANIZATION REPORT NUMBER

U.S. Army Engineer Research and Development Center

Cold Regions Research and Engineering Laboratory

ERDC/CRREL TR-06-1

72 Lyme Road

Hanover, NH 03755-1290

9. SPONSORING I MONITORING AGENCY NAME(S) AND ADDRESS(ES)

10. SPONSOR/MONITOR'S ACRONYM(S)

U.S. Army Corps of Engineers, New England District

USACE Wetlands Regulatory Assistance Program

11. SPONSOR/MONITOR'S REPORT NUMBER(S)

\section{DISTRIBUTION I AVAILABILITY STATEMENT}

Approved for public release; distribution is unlimited.

Available from NTIS, Springfield, Virginia 22161.

13. SUPPLEMENTARY NOTES

\section{ABSTRACT}

The Israel River in Lancaster, NH, has experienced numerous significant ice jams. In 1981 the New England Division of the U.S. Army Corps of Engineers completed an ice control structure (ICS) located about 0.5 miles upstream from the center of town. The 9-ft-high concrete-capped gabion weir was designed to retain both frazil ice during freezeup and broken ice after ice cover breakup. In recent years, the ICS has fallen into disrepair. The structure's current condition, combined with operation and maintenance safety issues and concerns about fish passage, have prompted the town to pursue the option of its removal. New England District Corps of Engineers, through the Corps' Wetlands Regulatory Assistance Program (WRAP), requested CRREL's assistance in determining whether the ICS has been effective in reducing the impacts of ice jams since its construction 24 years ago. Study results show that while the frequency of ice jam events in Lancaster has not decreased, the severity of ice jam flooding has, even though winter conditions at the time of the events have not lessened. The results of this preliminary analysis indicate that the Israel River ICS does provide some flood damage reduction benefit to the Town of Lancaster.

\section{SUBJECT TERMS}

Ice control structures

Ice jams

16. SECURITY CLASSIFICATION OF:

a. REPORT
$\mathrm{U}$

U

Israel River

Lancaster, NH

b. ABSTRACT
$\mathrm{U}$

$\mathrm{U}$

c. THIS PAGE

\begin{tabular}{|c|c|}
\hline 17. LIMITATION & 18. NUMBER \\
OF ABSTRACT & OF PAGES \\
& \\
$\mathrm{n}$ & 41 \\
\hline
\end{tabular}

19a. NAME OF RESPONSIBLE PERSON

19b. TELEPHONE NUMBER (include area code) 